\title{
Causal assessment of dietary acid load and bone disease: a systematic review \& meta-analysis applying Hill's epidemiologic criteria for causality
}

Tanis R Fenton ${ }^{1,2^{*}}$, Suzanne C Tough ${ }^{1}$, Andrew W Lyon ${ }^{3,4}$, Misha Eliasziw ${ }^{1}$ and David A Hanley ${ }^{1,5}$

\begin{abstract}
Background: Modern diets have been suggested to increase systemic acid load and net acid excretion. In response, alkaline diets and products are marketed to avoid or counteract this acid, help the body regulate its $\mathrm{pH}$ to prevent and cure disease. The objective of this systematic review was to evaluate causal relationships between dietary acid load and osteoporosis using Hill's criteria.
\end{abstract}

Methods: Systematic review and meta-analysis. We systematically searched published literature for randomized intervention trials, prospective cohort studies, and meta-analyses of the acid-ash or acid-base diet hypothesis with bone-related outcomes, in which the diet acid load was altered, or an alkaline diet or alkaline salts were provided, to healthy human adults. Cellular mechanism studies were also systematically examined.

Results: Fifty-five of 238 studies met the inclusion criteria: 22 randomized interventions, 2 meta-analyses, and 11 prospective observational studies of bone health outcomes including: urine calcium excretion, calcium balance or retention, changes of bone mineral density, or fractures, among healthy adults in which acid and/or alkaline intakes were manipulated or observed through foods or supplements; and 19 in vitro cell studies which examined the hypothesized mechanism. Urine calcium excretion rates were consistent with osteoporosis development; however calcium balance studies did not demonstrate loss of whole body calcium with higher net acid excretion. Several weaknesses regarding the acid-ash hypothesis were uncovered: No intervention studies provided direct evidence of osteoporosis progression (fragility fractures, or bone strength as measured using biopsy). The supporting prospective cohort studies were not controlled regarding important osteoporosis risk factors including: weight loss during follow-up, family history of osteoporosis, baseline bone mineral density, and estrogen status. No study revealed a biologic mechanism functioning at physiological pH. Finally, randomized studies did not provide evidence for an adverse role of phosphate, milk, and grain foods in osteoporosis.

Conclusions: A causal association between dietary acid load and osteoporotic bone disease is not supported by evidence and there is no evidence that an alkaline diet is protective of bone health.

\section{Background}

The concept that the modern diet produces excess acid, which causes several diseases of modern societies, and that "alkaline diets" prevent and cure these diseases are marketed to the general public across the globe. The public is being encouraged to measure their urine and/ or salivary $\mathrm{pH}$ to assess their health status and their risk of disease [1-4]. Marketers claim that alkaline diets and

\footnotetext{
* Correspondence: tanisfenton@shaw.ca

'Department of Community Health Sciences, University of Calgary, Calgary, AB, Canada

Full list of author information is available at the end of the article
}

related commercial products counteract acidity, help the body regulate its $\mathrm{pH}$, and thus prevent disease processes including osteoporosis, cancer, and cardiovascular disease through websites, (e.g. [1-4]) flyers, magazines, direct mail marketing, and books [5-8] directed to lay audiences. A Google search of "acid ash diet" and "alkaline diet" resulted in 1.4 million and 400,000 hits respectively. As well, the acid-ash hypothesis has been broadly stated as a major modifiable risk factor for bone loss in osteoporosis in well cited scientific papers $[9,10]$, textbooks [11], reference work [12], a government-funded workshop summary [13], and lay literature.

\section{Biomed Central}


According to the acid-ash hypothesis, high dietary protein intakes are detrimental to bone health since protein is an important "acid generating" diet component, and structural bone mineral is dissolved to release bicarbonate to neutralize acid and avoid systemic acidosis [9,14-16]. A recent narrative review claimed: "acid-yielding diets (cereal grains and most dairy products) cause urinary calcium loss [and] accelerated skeletal calcium depletion..." [17]. Dietary protein associated increased urinary calcium has been considered confirmation of this theoretical effect $[15,18-21]$.

Some critical reviews of the acid ash hypothesis have been undertaken with regards to bone health (in terms of the biochemistry [22-25], the role of protein [26,27], and phosphate [28], calcium balance [29], and the hypothesis in general [30]), however, to our knowledge, no systematic review has been done to assess the strength of the evidence of the acid ash hypothesis in terms of the etiology of osteoporosis.

The purpose of this systematic review was to evaluate causal relationships between the dietary acid load and osteoporosis among adults, and to assess the evidence using Hill's Criteria. The specific objectives were to examine the evidence that lowering the diet acid load alters the risk of osteoporosis progression by: a) conducting a thorough search of the literature for randomized human intervention and prospective observational studies and in vitro bone studies, of the dietary acid load and osteoporosis; b) performing meta-analyses of urine calcium, calcium balance, changes of bone mineral density (BMD), fractures, changes in bone strength, and bone resorption marker (BR marker); c) evaluating the prospective observational studies for osteoporosis risk factors that were controlled and not controlled in the analysis; d) reviewing the in vitro experimental findings to determine the $\mathrm{pH}$ at which increased bone resorption took place. Additional objectives of this study were to examine the exposures, the purported detrimental aspects of the diet acid load, for internal consistency, that is whether the food and urine estimates of the hypothesis were consistent with the whole hypothesis. We used Hill's criteria of causation [31] to assist in the assessment of causal relationships between exposures and disease [32,33], in this case, between the acid load of the modern diet and osteoporosis. Low quality trials are much more likely to demonstrate a benefit from an intervention [34-36], thus experts recommend that systematic reviews report meta-analyses restricted to trials at low risk of bias either as the primary analysis or in conjunction with less restrictive analyses [36]. Therefore we evaluated the included studies for their risks of bias, and focused the meta-analyses on high quality studies.

\section{Methods}

The Preferred Reporting Items for Systematic Reviews and Meta-analyses (PRISMA) Statement [37] was used to guide this study.

\section{Definitions}

Diet acid load - residual or excess hydrogen ion production post food metabolism

Net acid excretion - NAE = sum of urinary titratable acid and ammonium ion minus bicarbonate, usually measured in 24-hour urines

Osteoporosis - "a skeletal disorder characterized by compromised bone strength predisposing a person to an increased risk of fracture. Bone strength primarily reflects the integration of bone density and bone quality" [38].

\section{Eligibility Criteria}

Inclusion criteria

1) Randomized intervention, 2) prospective observational (cohort) human studies, and 3) in vitro animal studies of the mechanism of the acid-ash hypothesis among adults. Only studies of adults were included to avoid the potential confounding of growth and the variable timing of growth spurts. Random intervention studies were included if a) acid-base intake was manipulated through supplemental salts (such as potassium bicarbonate) or through foods to decrease the diet acid load (referred to in this text as the "alkaline diet") for, b) at least 24-hours to avoid variability due to diurnal variation, and c) outcomes related to bone health or osteoporosis (bone strength as measured with biopsy, fractures, change of $\mathrm{BMD}$, calcium balance, bone resorption markers, urine calcium) were evaluated. Calcium balance studies were only included if the recommendations of the Institute of Medicine [39] for this type of study were followed, including control of calcium intake for at least 7 days prior to the measurement of outcomes, provision and precise measurement of the food to the subjects, and chemical analysis of calcium in the food.

\section{Exclusion criteria}

1) studies with no original research (narrative reviews, editorials), 2) non-human studies (except for the in vitro mechanism studies), 3) studies with no control group, 4) non-prospective studies (cross-sectional or ecologic design studies). Randomized studies were favored since randomization is an indicator of rigor that reduces the probability of bias or confounding by known and unknown variables, with "numerous advantages and no disadvantages" [40]. This requirement for randomization was also applied to cross-over trials, since randomization to the order of treatments is important since 
without random allocation, the first treatment could influence the second period results [41].

Since the intent of this systematic review was to summarize the evidence regarding the potential for manipulation of the diet acid load as a therapy or prevention of osteoporosis for apparently healthy subjects, trials were included only if the nutritional intakes used could be recommended safely, not less than the Dietary Reference Intakes or higher than the Tolerable Upper Limits $[39,42]$. Studies were excluded if the subjects had conditions such as renal diseases, or were in states (such as asphyxia, diabetic keto-acidosis, drug abuse, poisoning, calorie restriction, or decreased ambulation) which could alter the effect of the exposure on the outcome.

\section{Literature Search}

In an attempt to find all published literature on the topic, studies relating to the acid-ash diet hypothesis and bone health were identified through computerized searches using, but not limited to, the medical subject headings and textwords, first: acid, alkaline, acid-ash, acid-base, modern, western, diet, calcium, phosphate, acid-base equilibrium, acid excretion, net acid excretion, bone or bones, osteoporosis, urine, balance/retention, biopsy, fracture(s), bone mineral, and bone mineral density. Second, to find studies that have examined proposed mechanisms for the hypothesis, we used the terms hydrogen-Ion concentration, cells (cultured), and mechanism. Databases searched included Medline back to 1966 (PubMed), Cochrane Database of Systematic Reviews, CINAHL back to 1982, EMBASE back to 1980, and the Cochrane Controlled Trials Register, up to August 2010. A Librarian (DL) was consulted regarding the literature search. In an effort to include all available studies, reference lists were reviewed for additional relevant articles. The literature search was not limited to English language articles.

Article titles were examined for potential fit to the inclusion criteria by one reviewer (TRF). When the title was not clear regarding the potential fit, the abstract was reviewed; when the abstract was not clear regarding whether the study fit the inclusion criteria, the paper was reviewed. Authors were contacted for additional information. Two authors (SCT \& TRF) independently rated the randomized studies for their risk of bias using the Cochrane Risk of Bias Tool [43]; two (AWL \& TRF) extracted the BR marker data; and two (ME \& DAH) extracted the potential confounders controlled in the cohort studies. Differences of opinion were resolved by discussion to achieve consensus.

After the data, including exposures and outcomes, was extracted and described in tables, the risk of bias of the randomized studies was assessed using the Cochrane
Risk of Bias Tool [43], for the randomized studies of the acid ash hypothesis by SCT and TRF.

\section{Meta-Analysis Methods}

To address the questions of what evidence supports the acid-ash hypothesis for the role of net acid excretion (NAE) and phosphate in urinary calcium excretion and calcium balance, we used the highest quality of evidence available, meta-analyses of random control trials (RCTs) or random cross-over studies (RCO). When meta-analyses were not found that fit the inclusion criteria and randomized trials were found that did meet the criteria, then meta-analyses were performed. When the exposure was a continuous measure, then linear regression analyses, weighted for sample size, were used to combine the results from the included studies to examine the effect of NAE and dietary phosphate on urinary calcium excretion and calcium balance.

To examine the effect of an alkaline treatment or a reduced "acid" diet load on the changes of resorptive bone resorption markers (BR markers) (i.e. serum C-telopeptide (CTX), urine N-telopeptide, and urine deoxypyridinoline crosslinks) using meta-analysis techniques, the exposures were considered as alkaline versus control, and standardized mean differences were calculated using fixed and/or random effects models, with Cochrane RevMan5 (Version 5.0. Copenhagen, The Cochrane Collaboration, 2008). If the p-value for heterogeneity was between 0.05 and 0.5 , then a random effects model was used [44]. The BR marker changes from baseline were used when baseline values were available in the RCTs, or the differences between the groups if baseline values were not available. Urine CTX was not included since it is considered less valid than serum CTX due to higher biological variation [45]. Then a second meta-analysis was performed as a sensitivity analysis, on the BR markers measured in a fasting state and at the same time of day as recommended to decrease measurement errors $[46,47]$. A difference greater than $30 \%$ for serum markers or $50-60 \%$ for urine markers were considered clinically important $[46,47]$.

The in-vitro cell culture studies of bone demineralization at varying $\mathrm{pH}$ were examined to determine the $\mathrm{pH}$ of testing and to summarize the effects revealed within the physiological $\mathrm{pH}$ range.

Prospective observational studies of the acid-ash hypothesis were examined for whether they supported or did not support the hypothesis, as well as which osteoporosis risk factors [48-52] were controlled for in the analysis.

Hill's criteria of causation [31] (Table 1) was used to evaluate the possibility of causation by the acid load of the modern diet on the etiology or potentiation of osteoporosis. Hill's criteria include: whether the 
Table 1 HILL'S CRITERIA OF CAUSATION

\begin{tabular}{ll}
\hline Criteria & Description \\
\hline TEMPORALITY & $\begin{array}{l}\text { An exposure must be measured prior the disease, for it to be clear which variable might be the cause and which variable } \\
\text { might be the result. }\end{array}$ \\
\hline STRENGTH & This criterion requires that the putative cause of an illness be of sufficient strength of association to cause disease. \\
\hline BIOLOGICAL & This criterion requires that when the dose of an exposure is increased, the risk of the outcome should also increase \\
\hline PLAUSIBILITY & This criterion requires that a theory fit with current biological knowledge. \\
\hline CONSISTENCY & This criterion requires consistent evidence from a variety of study designs to support a causal relationship \\
\hline EXPERIMENT & This criterion requires that actual experiments be conducted to determine whether the frequency of a disease is altered by an \\
\hline
\end{tabular}

exposure precedes the disease in time (Temporality), whether a dose-response or Biological Gradient relationship exists, the Strength of the evidence, whether the concept is Biologically Plausible, whether the evidence has Consistent findings between the studies of various designs, and whether actual Experiments have been done to determine whether altered exposure results in changes in disease frequency [31].

\section{Results}

\section{Description of Studies}

Out of 2165 references identified, fifty-five of 238 studies of the acid-ash hypothesis met the inclusion criteria (Figure 1). Twenty-two randomized intervention studies [14,20,53-72] (Table 2), two meta-analyses [27,29], and 12 prospective observational cohort studies (Table 3) [73-84] of the hypothesis met the inclusion criteria for at least one part of the study. Nineteen in-vitro animal bone mechanism studies were located [85-103]. The outcomes in the randomized intervention studies included: two examined changes of bone mineral density (BMD) [65,68], 15 examined calcium absorption and/or balance $[14,20,53,55-62,67,69-71]$, five examined changes of urine calcium without calcium balance [54,63,64,66,72], 12 examined changes in BR markers [14,57,59-61,65,67-72], and none reported fractures or bone strength. The 12 prospective observational (cohort) studies examined fractures $[73,74,80,81]$ and/or changes of BMD [75-79,82-84].

Using the Cochrane Risk of Bias Tool [43] to assess the risk of bias of the randomized studies, all studies were assessed as having a low risk of bias in terms of blinding [43] since the outcomes were objective measures. All of the studies were ranked by two authors as having a low risk of bias for sequence generation and complete data accounted for (Table 2). Only one study [65] was rated as having a high risk of selective outcome reporting bias. In terms of allocation concealment, only one study [68] demonstrated adequate procedures to avoid this risk of bias. The identified risks of bias ranged from zero to two risks of bias, with only one study rated as free of potential bias [68] (Table 2).
To quantify the acid or alkali load exposure, in the randomized trials, 12 of the 22 reported a measure of net acid excretion (NAE), a urinary measure of acid excretion, and one reported net endogenous acid production, an estimation of acid excretion based on food intake and body size. Three of the studies provided an alkaline or acid intervention in terms of bicarbonate salt, three others with a phosphate salt, and the final three studies altered protein intake, considered by the researchers to be an acid exposure.

Some acid-ash hypothesis studies, some that have been frequently quoted in the lay literature, were ineligible for inclusion because they were not randomized [9,15,18,21,104-131], had unclear methodology [132], and randomization was questionable due to high baseline differences between the two groups [133]. One well quoted study incorporated a salt intake dose of 225 $\mathrm{mmol} /$ day (5.2 gram/day) for both the potassium citrate and placebo groups [134] that was more than twice the Tolerable Upper Limit of 2.3 gram/day [12]. Two studies used a protein intake that were less than the recommended Dietary Reference Intake in one arm of each study, so that arm was not included $[56,70]$. Two meta-analyses of intervention studies of the hypothesis were not included since they did not limit inclusion to randomized trials $[28,135]$. Numerous studies were cross-sectional observation [19,73,136-173] or ecologic studies $[174,175]$ (which lack the ability to assess temporality) did not meet the inclusion criteria. One casecontrol study was located [176] was not included because the design is not well suited to assessing causality (eg recall bias, retrospective data collection) [41].

Other reasons for excluding studies were: No numerical results presented and no response to a written request $[177,178]$; more than one simultaneous intervention [179-190], a simultaneous co-intervention of change of "acid" as well as other potentially bone influencing nutrients including calcium, sodium, potassium, magnesium, and/or phosphate [130,191-194], hypothesis generating studies that lack a no-intervention control group [195-197], time periods were shorter than 24 hours 


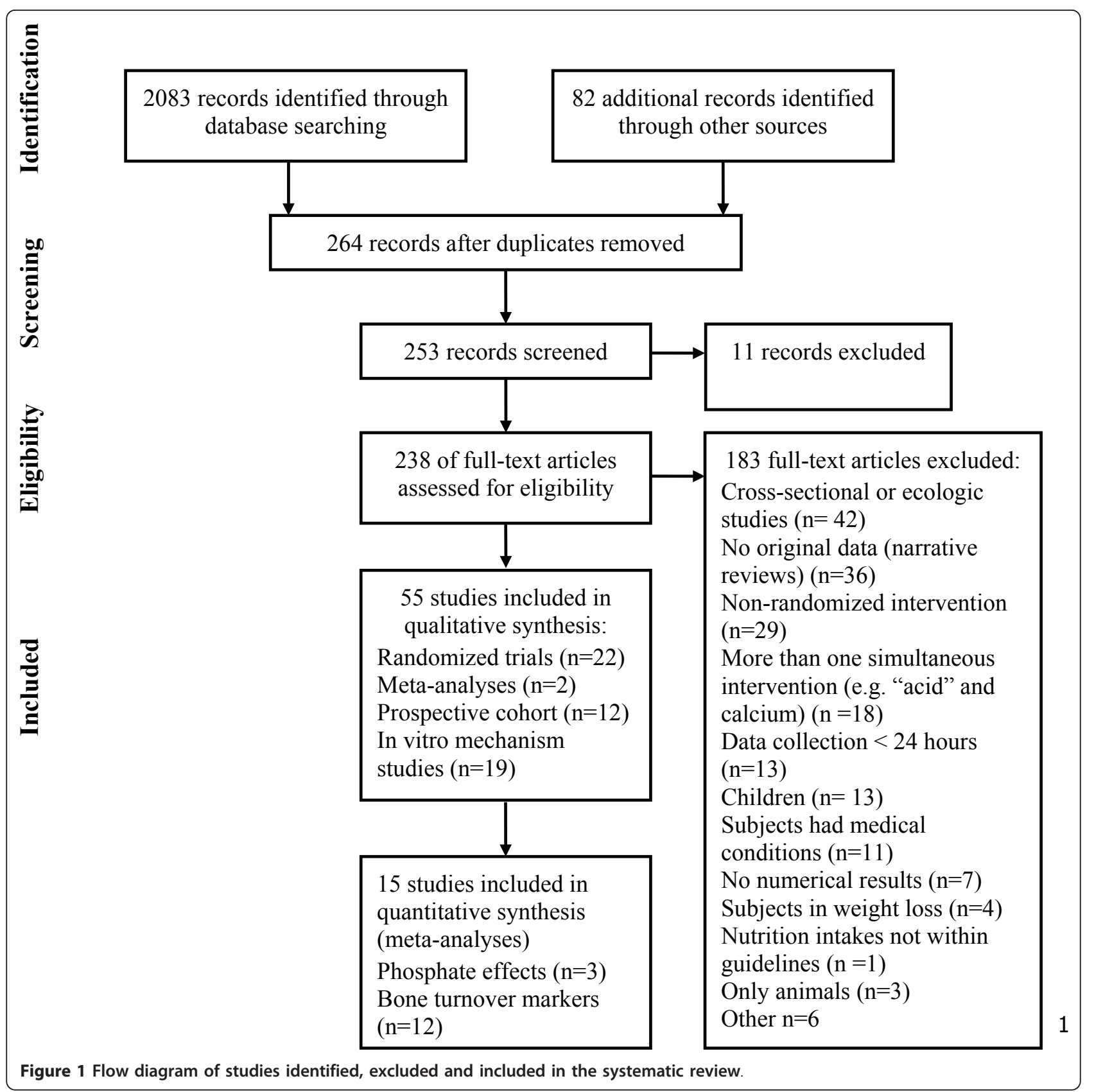

[198-210], did not include outcomes required in the inclusion criteria [211]; all of the subjects had a chronic medical condition [124,212-220], were on medications [221], or were in a state of weight loss [222-225], only included children [106-108,137,138,141-143,145,149,155,166,202], or only included animals [226-228]. Two studies [229,230] were subsets of included studies [56,75]. The search also located numerous narrative review articles on the acid-ash hypothesis [10,16,22-26,132,231-258] which did not qualify for inclusion in this systematic review. No foreign language articles $[124,130,231]$ met the inclusion criteria.
Urine calcium and calcium balance studies - Acid excretion Based on a meta-analysis that met the inclusion criteria of this systematic review, the estimated excess calciuria from the diet acid load is $66 \mathrm{mg} /$ day (Confidence inter$\mathrm{val}=60$ to $71 \mathrm{mg} /$ day $)(1.6 \mathrm{mmol} /$ day, confidence inter$\mathrm{val}=1.5$ to $1.8 \mathrm{mmol} /$ day), based on diets designed to represent the modern acid-generating diet [135]. If this calcium loss estimated from short term studies were extrapolated over time, without adaption, a continuous loss of $66 \mathrm{mg} /$ day would lead to 24 grams/year or 480 grams over 20 years. 
Table 2 Randomized intervention Human Studies that Met the Inclusion Criteria

\begin{tabular}{|c|c|c|c|c|c|c|c|c|}
\hline \multirow[b]{2}{*}{ Study } & \multirow[b]{2}{*}{ Design } & \multirow[b]{2}{*}{ Exposures } & \multirow[b]{2}{*}{$\begin{array}{l}\text { Exposure } \\
\text { quantified }\end{array}$} & \multirow[b]{2}{*}{ Outcomes } & \multicolumn{4}{|c|}{ Cochrane Risk of Bias Assessment } \\
\hline & & & & & $\begin{array}{l}\text { Sequence } \\
\text { generation }\end{array}$ & $\begin{array}{l}\text { Allocation } \\
\text { concealment }\end{array}$ & $\begin{array}{l}\text { Incomplete } \\
\text { outcome data }\end{array}$ & $\begin{array}{l}\text { Selective } \\
\text { outcome } \\
\text { reporting }\end{array}$ \\
\hline Patton [53] & $\mathrm{RCO}$ & Phosphate salt & $\mathrm{mg} P$ & Calcium balance & low & High & low & low \\
\hline Breslau [20] & $\mathrm{RCO}$ & Protein foods & NAE & $\begin{array}{l}\text { Urine calcium \& } \\
\text { absorption }\end{array}$ & low & High & low & Low \\
\hline Whybro* [54] & $\mathrm{RCO}$ & Phosphate salt & $\mathrm{mmol} P$ & Urine calcium & part $1=$ low & High & low & low \\
\hline Dahl [55] & $\mathrm{RCO}$ & Lentils & NAE & Calcium balance & low & High & low & low \\
\hline $\begin{array}{l}\text { Kerstetter } \\
{[56]}\end{array}$ & $\mathrm{RCO}$ & $\begin{array}{l}\text { Amount of } \\
\text { protein }\end{array}$ & g protein & $\begin{array}{l}\text { Urine calcium, } \\
\text { absorption \& BTM }\end{array}$ & low & High & low & low \\
\hline Buclin [14] & $\mathrm{RCO}$ & Acid diet & No & Urine calcium \& BTM & low & High & low & low \\
\hline $\begin{array}{l}\text { Roughead } \\
\text { [57] }\end{array}$ & $\mathrm{RCO}$ & $\begin{array}{l}\text { Amount of } \\
\text { protein }\end{array}$ & NAE & $\begin{array}{l}\text { Calcium balance \& } \\
\text { BTM }\end{array}$ & low & High & low & low \\
\hline $\begin{array}{l}\text { Dawson- } \\
\text { Hughes [58] }\end{array}$ & $\mathrm{RCT}$ & $\begin{array}{l}\text { Amount of } \\
\text { protein }\end{array}$ & $\mathrm{g}$ protein & Urine calcium \& BTM & low & High & low & low \\
\hline $\begin{array}{l}\text { Roughead } \\
\text { [59] }\end{array}$ & $\mathrm{RCO}$ & Meat/soy & NAE & $\begin{array}{l}\text { Calcium balance \& } \\
\text { BTM }\end{array}$ & low & High & low & low \\
\hline Sakhaee [60] & $\mathrm{RCO}$ & K+citrate & K+citrate & $\begin{array}{l}\text { Urine calcium, } \\
\text { absorption \& BTM }\end{array}$ & low & High & low & low \\
\hline Spence [61] & $\mathrm{RCO}$ & $\begin{array}{l}\text { Soy vs. milk } \\
\text { protein }\end{array}$ & NAE & $\begin{array}{l}\text { Calcium balance \& } \\
\text { BTM }\end{array}$ & low & High & low & low \\
\hline $\begin{array}{l}\text { Kerstetter } \\
\text { [62] }\end{array}$ & $\mathrm{RCO}$ & $\begin{array}{l}\text { Amount of } \\
\text { protein }\end{array}$ & NAE & Calcium balance & low & High & low & low \\
\hline Kemi [66] & $\mathrm{RCO}$ & Phosphate salt & mg P & Urine calcium & low & High & low & low \\
\hline $\begin{array}{l}\text { Kerstetter } \\
{[67]}\end{array}$ & $\mathrm{RCO}$ & $\begin{array}{l}\text { Amount \& type } \\
\text { of protein }\end{array}$ & NAE & $\begin{array}{l}\text { Calcium balance \& } \\
\text { BTM }\end{array}$ & low & High & low & low \\
\hline Hunt [69] & $\mathrm{RCO}$ & Protein & $\begin{array}{l}\text { g protein, mg } \\
\mathrm{Ca}\end{array}$ & $\begin{array}{l}\text { Calcium balance \& } \\
\text { BTM }\end{array}$ & low & High & low & low \\
\hline Ceglia* [70] & $\mathrm{RCT}$ & K+bicarbonate & NAE & $\begin{array}{l}\text { Urine calcium and } \\
\text { absorption }\end{array}$ & low & High & low & low \\
\hline $\begin{array}{l}\text { Dawson- } \\
\text { Hughes [70] }\end{array}$ & $\mathrm{RCT}$ & K+bicarbonate & NAE & Urine calcium \& BTM & low & High & low & low \\
\hline Frassetto [63] & $\mathrm{RCT}$ & K+bicarbonate & $\begin{array}{l}\text { K } \\
\text { +bicarbonate }\end{array}$ & Urine calcium & low & High & low & low \\
\hline Gettman [64] & $\mathrm{RCO}$ & Cranberry juice & NAE & Urine calcium & low & High & low & low \\
\hline Karp [72] & $\mathrm{RCO}$ & K+citrate & K+citrate & Urine calcium \& BTM & low & High & low & low \\
\hline Jehle [65] & $\mathrm{RCT}$ & K+citrate & NAE & BMD \& BTM & low & High & low & High \\
\hline $\begin{array}{l}\text { MacDonald } \\
\text { [79] }\end{array}$ & $\mathrm{RCT}$ & $\begin{array}{l}\text { K+citrate/fruit \& } \\
\text { veg }\end{array}$ & NEAP & BMD \& BTM & low & low & low & low \\
\hline
\end{tabular}

Among the studies included in this meta-analysis [135], investigators exposed subjects to a wide range of acid or base treatments, between a decrease NAE of 57 [70] to an increase of 69 [62] milliequivalent/day. As NAE is increased, the excretion of calcium in the urine also increased. For every milliequivalent increase of $\mathrm{NAE}$, urine calcium increased by $0.03 \mathrm{mmol} /$ day $(95 \%$ confidence interval $(\mathrm{CI})=0.023$ to $0.035, \mathrm{p}<0.0001)(\mathrm{n}$ = 133) (Figure 2) [29]. However, a meta-analysis of five randomized calcium balance studies with superior methodology revealed no evidence that diet changes that raise NAE lowers calcium balance $(\mathrm{n}=77, \mathrm{p}=0.38)$ (Figure 3) [29].
A randomized calcium balance study was published since this meta-analysis [29] was completed. This randomized trial of two levels of protein intake on calcium metabolism by Hunt et al. [69] found that higher protein intakes were not detrimental to calcium retention since higher protein increased calcium absorption in similar quantity to the rise in urine calcium, even when calcium intakes were low [69].

Urine calcium and calcium balance studies - Phosphate Studies

Phosphate. In a meta-analysis of the influence of phosphate supplements on calcium metabolism, limited to randomized studies that followed the recommendations 
Table 3 Prospective Observational Studies that met the Inclusion Criteria

\begin{tabular}{|c|c|c|c|c|c|c|c|}
\hline Study & Year & Population & Exposures & Outcomes & Results & $\begin{array}{l}\text { Potential confounders } \\
\text { controlled or stratified }\end{array}$ & $\begin{array}{l}\text { Potential } \\
\text { confounders not } \\
\text { controlled }\end{array}$ \\
\hline Feskanich & 1996 & $\begin{array}{l}\text { Women } 35 \text { to } 59 \\
\text { years }\end{array}$ & Protein intake & Fractures & $\begin{array}{l}\text { Protein intake was } \\
\text { associated with increased } \\
\text { risk of forearm fracture; } \\
\text { no association between } \\
\text { protein intake and hip } \\
\text { fractures. }\end{array}$ & $\begin{array}{l}\text { Age, BMI, change of BMI, } \\
\text { estrogen status, smoking, } \\
\text { energy intake, physical } \\
\text { activity, calcium, } \\
\text { potassium, and vitamin } \\
\text { D intakes. }\end{array}$ & $\begin{array}{l}\text { Family history of } \\
\text { osteoporosis, } \\
\text { baseline BMD }\end{array}$ \\
\hline Munger & 1999 & $\begin{array}{l}\text { Postmenopausal } \\
\text { women }\end{array}$ & Protein intake & $\begin{array}{l}\text { Hip } \\
\text { fractures }\end{array}$ & $\begin{array}{l}\text { Protein intake was } \\
\text { associated with lower } \\
\text { hip fracture risk. }\end{array}$ & $\begin{array}{l}\text { Age, body size, parity, } \\
\text { smoking, alcohol intake, } \\
\text { estrogen use, physical } \\
\text { activity }\end{array}$ & $\begin{array}{l}\text { Weight loss } \\
\text { during follow-up, } \\
\text { family history of } \\
\text { osteoporosis, } \\
\text { baseline BMD, } \\
\text { vitamin D status, } \\
\text { calcium intake }\end{array}$ \\
\hline Tucker & 2001 & $\begin{array}{l}\text { Adults } 69 \text { to } 97 \\
\text { years }\end{array}$ & $\begin{array}{l}\text { Fruit \& vegetable } \\
\text { nutrients, \& protein }\end{array}$ & $\begin{array}{l}\text { Change of } \\
\text { BMD }\end{array}$ & $\begin{array}{l}\text { Potassium, fruit \& } \\
\text { vegetable intakes among } \\
\text { men were associated } \\
\text { with less BMD loss. } \\
\text { Protein intakes were } \\
\text { associated with less BMD } \\
\text { loss. }\end{array}$ & $\begin{array}{l}\text { Energy intake, age, sex, } \\
\text { weight, BMl, smoking, } \\
\text { caffeine, alcohol intake, } \\
\text { physical activity, calcium } \\
\text { intake, calcium and/or } \\
\text { vitamin D supplements, } \\
\text { season, current estrogen } \\
\text { use. }\end{array}$ & $\begin{array}{l}\text { Weight loss } \\
\text { during follow-up, } \\
\text { family history of } \\
\text { osteoporosis, } \\
\text { baseline BMD }\end{array}$ \\
\hline Promislow & 2002 & $\begin{array}{l}\text { Adults } 55 \text { to } 92 \\
\text { years }\end{array}$ & Protein intake & $\begin{array}{l}\text { Change of } \\
\text { BMD }\end{array}$ & $\begin{array}{l}\text { Protein intake was } \\
\text { associated with increased } \\
\text { BMD over } 4 \text { years. }\end{array}$ & $\begin{array}{l}\text { Energy intake, calcium } \\
\text { intake, diabetes, number } \\
\text { of years postmenopausal, } \\
\text { exercise, smoking, } \\
\text { alcohol, } \\
\text { thiazides, thyroid } \\
\text { hormones, steroids, and } \\
\text { estrogen, } \\
\text { body weight change }\end{array}$ & $\begin{array}{l}\text { Family history of } \\
\text { osteoporosis, } \\
\text { baseline BMD }\end{array}$ \\
\hline Kaptoge & 2003 & $\begin{array}{l}\text { Adults } 67 \text { to } 79 \\
\text { years }\end{array}$ & $\begin{array}{l}\text { Fruit, vegetables, } \\
\text { vitamin C }\end{array}$ & $\begin{array}{l}\text { Change of } \\
\text { BMD }\end{array}$ & $\begin{array}{l}\text { No associations between } \\
\text { nutrients and BMD loss. } \\
\text { In women, vitamin C } \\
\text { was associated with less } \\
\text { BMD loss. No } \\
\text { associations for fruit and } \\
\text { vegetable intakes. }\end{array}$ & $\begin{array}{l}\text { Sex, age, BMl, weight } \\
\text { change, physical activity, } \\
\text { smoking, family history, } \\
\text { energy intake. }\end{array}$ & $\begin{array}{l}\text { Baseline BMD, } \\
\text { estrogen status, } \\
\text { vitamin D status, } \\
\text { calcium intake }\end{array}$ \\
\hline Rapuri & 2003 & $\begin{array}{l}\text { Women } 65 \text { to } 77 \\
\text { years }\end{array}$ & Protein intake & $\begin{array}{l}\text { Change of } \\
\text { BMD }\end{array}$ & $\begin{array}{l}\text { No association between } \\
\text { protein intake and the } \\
\text { rate of bone loss. }\end{array}$ & $\begin{array}{l}\text { Age, BMI, intakes of } \\
\text { calcium, energy, fiber, } \\
\text { vitamin D status, and } \\
\text { alcohol, smoking, } \\
\text { physical activity. }\end{array}$ & $\begin{array}{l}\text { Weight loss } \\
\text { during follow-up, } \\
\text { baseline BMD, } \\
\text { family history of } \\
\text { osteoporosis }\end{array}$ \\
\hline MacDonald & 2004 & $\begin{array}{l}\text { Premenopausal } \\
\text { women }\end{array}$ & $\begin{array}{l}\text { Fruit \& vegetables } \\
\text { nutrients }\end{array}$ & $\begin{array}{l}\text { Change of } \\
\text { BMD }\end{array}$ & $\begin{array}{l}\text { Among menstruating } \\
\text { and perimenopausal } \\
\text { women, intakes of } \\
\text { vitamin } C \text { and } \\
\text { magnesium, but not } \\
\text { potassium, were } \\
\text { associated with change } \\
\text { of BMD. }\end{array}$ & $\begin{array}{l}\text { Age, weight, change in } \\
\text { weight, height, smoking, } \\
\text { physical activity, } \\
\text { socioeconomic status, } \\
\text { baseline BMD. }\end{array}$ & $\begin{array}{l}\text { Family history of } \\
\text { osteoporosis, } \\
\text { calcium intake, } \\
\text { vitamin D status }\end{array}$ \\
\hline $\begin{array}{l}\text { Dargent- } \\
\text { Molina }\end{array}$ & 2008 & $\begin{array}{l}\text { Postmenopausal } \\
\text { women }\end{array}$ & $\begin{array}{l}\text { Protein \& diet acid } \\
\text { load }\end{array}$ & Fractures & $\begin{array}{l}\text { No overall association } \\
\text { between protein intake } \\
\text { and acid excretion with } \\
\text { fracture risk; in the } \\
\text { lowest calcium intake } \\
\text { quartile, protein intake } \\
\text { was associated with } \\
\text { fracture risk }\end{array}$ & $\begin{array}{l}\text { Age, BMI, physical } \\
\text { activity, parity, maternal } \\
\text { history of hip fracture, } \\
\text { hormonal therapy, } \\
\text { smoking, alcohol, energy } \\
\text { intake. }\end{array}$ & $\begin{array}{l}\text { Weight loss } \\
\text { during follow-up, } \\
\text { baseline BMD, } \\
\text { vitamin D status. }\end{array}$ \\
\hline
\end{tabular}


Table 3 Prospective Observational Studies that met the Inclusion Criteria (Continued)

\begin{tabular}{|c|c|c|c|c|c|c|c|}
\hline Thorpe & 2008 & $\begin{array}{l}\text { Peri- and } \\
\text { Postmenopausal } \\
\text { women }\end{array}$ & Protein & $\begin{array}{l}\text { Wrist } \\
\text { fractures }\end{array}$ & $\begin{array}{l}\text { Protein intake was } \\
\text { associated with lower } \\
\text { risk of wrist fracture, for } \\
\text { both vegetable and } \\
\text { meat protein. }\end{array}$ & $\begin{array}{l}\text { Age, height, weight, BMI, } \\
\text { education, any fracture } \\
\text { since age 35, parity, } \\
\text { smoking, alcohol use, } \\
\text { diabetes mellitus, } \\
\text { rheumatoid arthritis, } \\
\text { physical activity, years } \\
\text { since menopause. }\end{array}$ & $\begin{array}{l}\text { Estrogen status, } \\
\text { calcium intake }\end{array}$ \\
\hline Pedone & 2009 & $\begin{array}{l}\text { Women } 60 \text { to } 96 \\
\text { years }\end{array}$ & $\begin{array}{l}\text { Potential renal acid } \\
\text { load }\end{array}$ & $\begin{array}{l}\text { Change of } \\
\text { BMD }\end{array}$ & $\begin{array}{l}\text { Protein intake was } \\
\text { associated with a lower } \\
\text { loss of BMD. }\end{array}$ & $\begin{array}{l}\text { Physical activity, energy } \\
\text { intake, renal function, } \\
\text { vitamin D status, } \\
\text { estrogen status, baseline } \\
\text { BMD. }\end{array}$ & $\begin{array}{l}\text { Weight loss } \\
\text { during follow-up, } \\
\text { family history of } \\
\text { osteoporosis, } \\
\text { calcium intake. }\end{array}$ \\
\hline Beasley & 2010 & $\begin{array}{l}\text { Women } 14 \text { to } 40 \\
\text { years }\end{array}$ & Protein intake & $\begin{array}{l}\text { Change of } \\
\text { BMD }\end{array}$ & $\begin{array}{l}\text { No association between } \\
\text { protein intake and } \\
\text { change of BMD. }\end{array}$ & $\begin{array}{l}\text { Age, race-ethnicity, age } \\
\text { of menarche, time since } \\
\text { menarche, family history } \\
\text { of fracture, BMl, physical } \\
\text { activity score, calories, } \\
\text { dietary calcium, } \\
\text { phosphorous, dietary } \\
\text { vitamin D, magnesium, } \\
\text { fluoride, alcohol, } \\
\text { smoking, contraceptive } \\
\text { use, prior pregnancy, } \\
\text { and education }\end{array}$ & \\
\hline Fenton & 2010 & Adults 25 years+ & $\begin{array}{l}\text { Urine } \mathrm{pH} \text {, urine } \\
\text { potassium, sodium, } \\
\text { calcium, magnesium, } \\
\text { phosphate, sulfate, } \\
\text { chloride, and acid } \\
\text { excretion, controlled } \\
\text { for urine creatinine }\end{array}$ & $\begin{array}{l}\text { Change of } \\
\text { BMD and } \\
\text { fractures }\end{array}$ & $\begin{array}{l}\text { No associations between } \\
\text { urine } \mathrm{pH} \text { or acid } \\
\text { excretion and either the } \\
\text { incidence of fractures or } \\
\text { change of BMD }\end{array}$ & $\begin{array}{l}\text { Age, gender, family } \\
\text { history of osteoporosis, } \\
\text { BMI, change in BMI, } \\
\text { baseline BMD, estrogen } \\
\text { status, kidney disease, } \\
\text { smoking, thiazide } \\
\text { diuretics, } \\
\text { bisphosphonates, } \\
\text { physical activity, calcium } \\
\text { intake, and vitamin D } \\
\text { status, urine creatinine, }\end{array}$ & \\
\hline
\end{tabular}

* $\mathrm{BMD}=$ bone mineral density; $\mathrm{BMI}=$ body mass index

of the Institute of Medicine for calcium balance studies [39], only one study met the inclusion criteria [53]. This cross-over study randomized young adult women to two phosphate doses $(300 \mathrm{mg}=10 \mathrm{mmol}$ and $600 \mathrm{mg}=20$ mmol) stratified by calcium intakes of $344 \mathrm{mg}(9 \mathrm{mmol})$ (basal diet) or with calcium supplements of 600 (15 $\mathrm{mmol}$ ) or $1200 \mathrm{mg}(30 \mathrm{mmol})$ per day. The regression analysis of the effect of phosphate on urine calcium revealed a statistically significant linear relationship (Figure 4). For every mmol increase in phosphate supplement, urine calcium decreased by $0.04 \mathrm{mmol} /$ day $(95 \%$ $\mathrm{CI}=-0.06$ to $-0.02, \mathrm{p}<0.001)$. For calcium balance, the relationship was in the opposite direction (Figure 5). For every mmol increase in phosphate supplement, calcium balance increased by $0.10 \mathrm{mmol} /$ day $(95 \% \mathrm{CI}=0.09$ to $0.12, \mathrm{p}<0.001)$.

\section{Protein}

Regarding the role of protein and bone demineralization, recent randomized cross-over studies of the amount $[57,62,67,69]$ and type (animal versus vegetable) [59] of protein, and a meta-analyses of superior methodology randomized cross-over studies of protein intakes on calcium balance [29] demonstrated that higher protein intakes and animal protein were not detrimental to calcium retention.

\section{Prospective observational studies}

Prospective observational studies measure an exposure prior to the outcome and therefore met the inclusion criterion of Temporality, but these studies are not randomized since the subjects chose their own lifestyles and the investigators only observe the outcomes. Twelve prospective observational cohort studies examined associations between either fruit and vegetable intakes, related nutrients $[75,77,79]$, protein intakes [73-76,78,80-82,84], or urine measures of acid excretion [83] with changes in BMD [75-79,82-84] and/or fractures $[73,74,80,81,83]$ as the outcomes (Table 3$)$. Five of these studies had some results that supported the acid-ash hypothesis [73,75,77,79,81]; while the results of seven studies did not support the hypothesis [74,76,80-84]. Each of the prospective cohort studies that supported the hypothesis also had some findings that did not support the hypothesis $[73,75,77,79,81]$. 


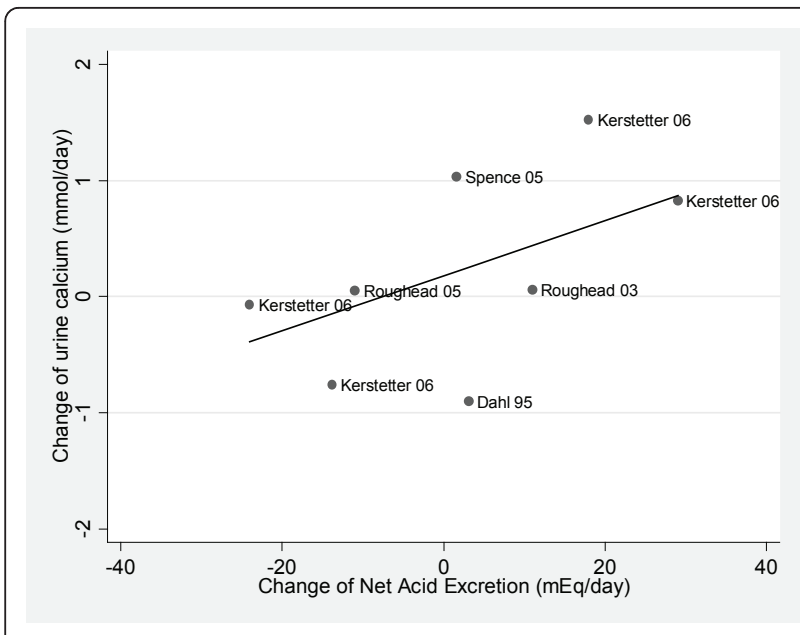

Figure 2 The relationship between change in NAE and change in urinary calcium, limited to randomized studies that followed the Institute of Medicines' guidelines for calcium metabolism studies ( $\mathbf{R} 2=\mathbf{0 . 4 0 6} ; \mathbf{p}<\mathbf{0 . 0 0 0 1})$. This material is reproduced with permission of John Wiley \& Sons, Inc. from Fenton et al. J Bone Miner Res 2009;24:1835-1840.

\section{In vitro studies of animal bone}

In vitro studies of animal bone demonstrated higher rates of bone demineralization when exposed to low $\mathrm{pH}$ below the physiological range $(\leq 7.3)$ and calcium release from bone [85], activation of osteoclasts [96], and enzyme activities [88]. None of the reports mentioned conducting tests within the physiological range [85-89,91,94-97,99,100,102] or at any $\mathrm{pH}$ greater than $7.2[89,94,96]$.

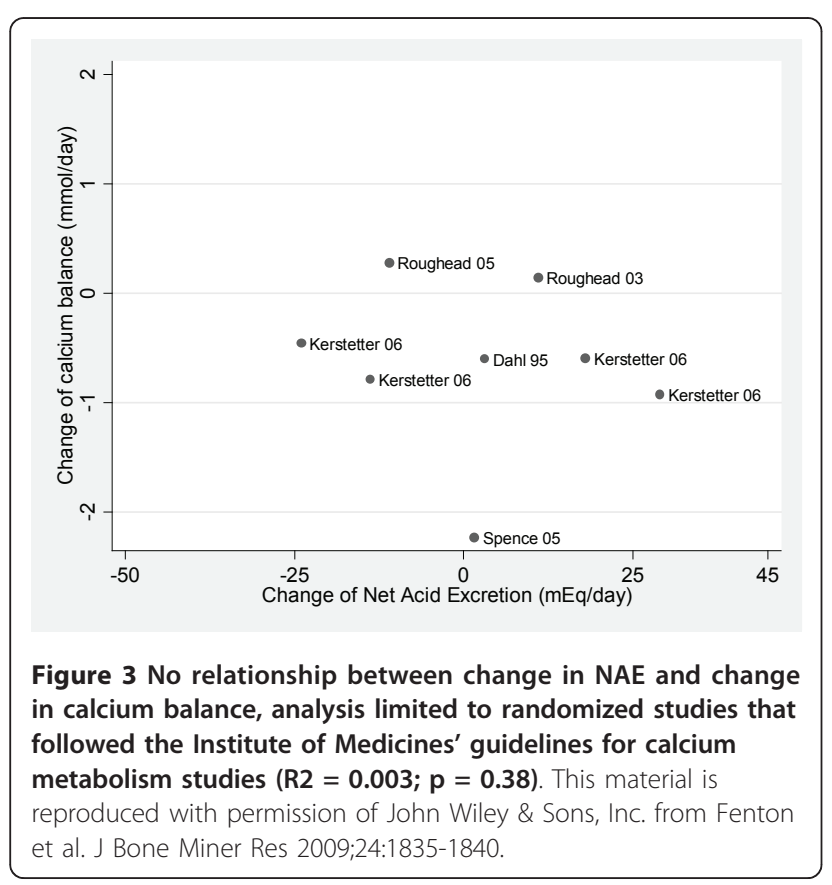

Bone outcomes used in the experimental studies of the acid ash hypothesis

No experimental studies were found that examined bone strength (which is considered the best outcome measures of osteoporosis, that is fragility fractures or bone strength as measured from bone biopsy samples $[259,260])$.

\section{Changes in Bone Mineral Density}

Two RCTs used changes of BMD as the outcome measure in post menopausal women with opposite BMD findings $[65,68]$. Both of these studies examined the effect of potassium citrate on the change of BMD over one [65] or two [68] years, and one also examined the effect of increased fruit and vegetable intakes [68].

The studies differed in quality by two important risk of Bias [43]: concealment of allocation and selective outcome reporting (Table 2). The study by MacDonald et al concealed their subject allocation to the groups [68], while the other study by Jehle et al did not [65]. The Jehle et al paper does not report their changes of BMD or BR markers numerically "so that they could be included in a meta-analysis" [43]. MacDonald et al found no effect of the potassium citrate, or increased fruit and vegetable intakes on BMD over time [68], while the Jehle et al study reported an increase in BMD at femoral neck $(P<0.001)$, and at total hip $(P<0.001)$ in the potassium citrate group.

\section{Bone resorption markers (BR markers)}

When all of the individual studies of alkaline treatments or reduced "acid" diet loads on the changes of BR markers were combined in a meta-analysis, the individual study findings were significantly heterogeneous ( $\mathrm{p}=$ 0.02) (Table 4) (Figure 6), thus the results from all the

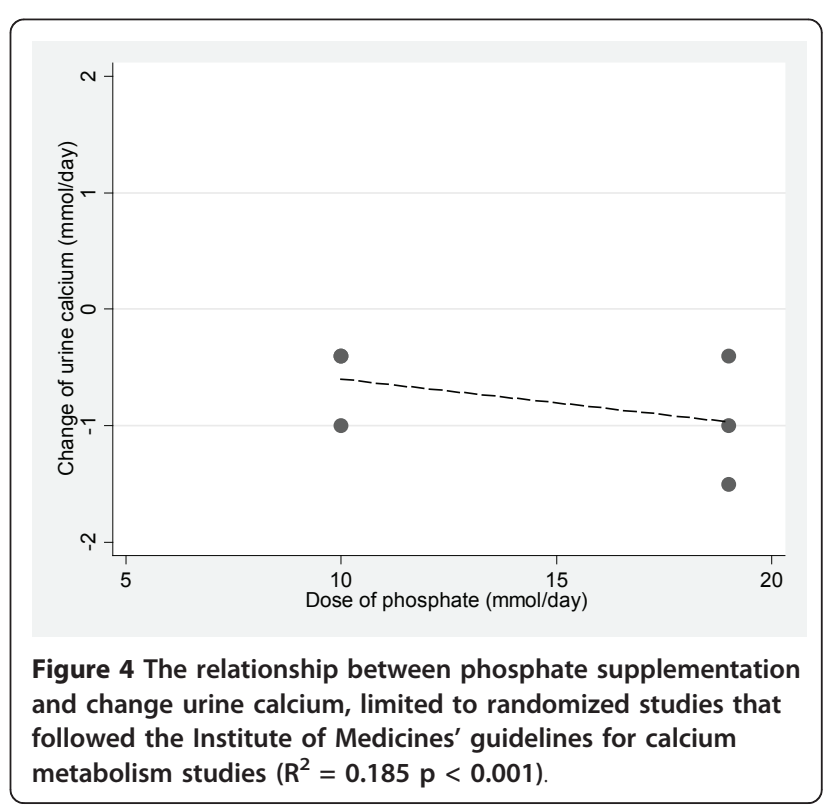




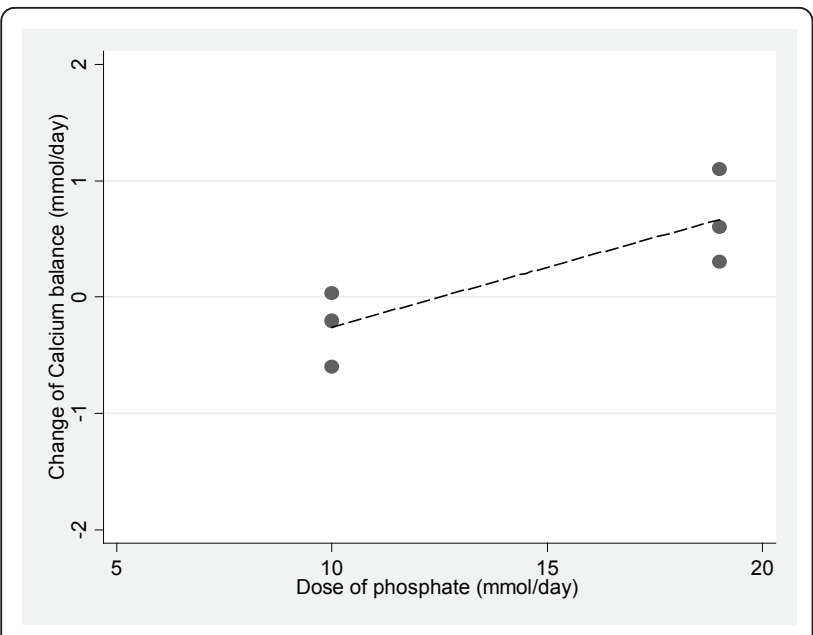

Figure 5 The relationship between phosphate supplementation and change calcium balance, limited to randomized studies that followed the Institute of Medicines' guidelines for calcium metabolism studies $\left(R^{2}=0.704, p<0.001\right)$.

studies should not be combined into a summary effect estimate [43]. In the sensitivity analysis, limited to samples collected under fasting conditions (Figure 7), the study results were sufficiently homogenous that the meta-analysis results could be considered (test of heterogeneity $\mathrm{p}$-value $=0.13$, non-significant), and a random effect model was used [44]. The estimated summary effect of an alkaline intake on BR markers taken under fasting conditions revealed no overall effect $(\mathrm{p}=0.76)$ in meta-analysis (Figure 7).

In terms of percent difference between study interventions in the individual studies, only one study reported a clinically important difference [46,47], a 52\% decrease of $\mathrm{N}$-telopeptide, collected under fasting conditions, in response to protein supplementation [58]. The results which were the opposite direction to that which the hypothesis would predict. Two individual studies found individual statistically significant decreases in their subjects' BR marker, both these changes in response to higher protein intakes $[58,69]$ were in the opposite direction to that which the hypothesis would predict, and one in the same direction [56]. The only statistically significant result that was in the direction the acid ash hypothesis would predict was in a study of bicarbonate supplementation [71]; this study was not included in the sensitivity analysis since the BR marker were not collected during fasting.

\section{Potassium}

None of the seven randomized intervention studies that altered potassium intake (using potassium bicarbonate) $[58,60,65,68,70-72]$ followed the recommendations for calcium balance studies, so they were not included in the systematic review of calcium balance. In terms of BR markers, in response to potassium bicarbonate or citrate, BR markers decreased by nine $[60,68]$ to 28 [72] percent. One prospective observational study, by Tucker at al., found an association between potassium intakes and fruit and vegetable intakes with less BMD loss [75]. The study by Tucker et al did not control for weight loss during follow-up, family history of osteoporosis, baseline BMD [75]. Additionally, this finding of association between potassium intakes and BMD loss by Tucker et al. was not substantiated by others $[77,79,83]$. Further, the study by Fenton et al found no association between urine potassium and either BMD loss or fractures [83].

\section{Protein and calcium interaction}

Regarding the assertion that that calcium and protein work in an interaction, such that protein is more detrimental when calcium intakes are low was supported by one observational study [81], but not supported by one randomized trial [69]. Dargent-Molina reported that among subjects in the lowest calcium intake quartile, protein intake was associated with higher fracture risk [81]. This study did not control for weight loss during follow-up, baseline BMD, and vitamin D status (Table 3) [81]. A randomized trial that examined the effect of two levels of calcium intake (700 vs. $1500 \mathrm{mg} /$ day) with two levels of protein intake (60 vs. $110 \mathrm{~g} /$ day) in a controlled feeding study of postmenopausal women found that the higher protein intakes increased calcium retention from the low-calcium but not the high-calcium diet, which does not support the hypothesis [69]. The protein effects on urine calcium were independent of calcium intake [69].

\section{Discussion of The Hill's Criteria Assessment Hill's Criterion \#1: Temporality}

An a priori criterion was to include only prospective studies (Table 1), therefore, cross-sectional or ecologic design studies were not included in this systematic review (Table 5). Knowing that the exposure preceded a disease is considered "the only absolutely essential criterion" of causation [41].

\section{Hill's Criterion \#2: Strength}

In terms of urine calcium, the magnitude of excess calciuria induced by the modern diet is sufficient to lead to the development of osteoporosis, or equivalent to an estimated loss of 480 grams over 20 years, almost half of the skeleton calcium [261]; a substantial loss of bone mineral, which would be considered rapidly progressing osteoporosis. Therefore, the calciuria associated with the modern diet is sufficient in quantity that it could explain the progression of osteoporosis, if the excess urine calcium is only derived from bone. In contrast, the evidence from studies of the diet acid load and calcium balance does not support the acid ash hypothesis 
Table 4 Change in Bone Resorption Markers in Response to a More Alkaline Diet

\begin{tabular}{|c|c|c|c|c|c|c|c|c|c|c|c|}
\hline 1st Author & year & $\mathrm{n}$ & Subjects & Comparison & Design & Change NAE & Marker & Fasting & Control & Alkaline & Percent change of marker \\
\hline Kerstetter & 1999 & 16 & Women 20 - 40 years & High vs medium pro & RCO & & $\mathrm{NTX} / \mathrm{Cr}$ & yes & $48.2(29)$ & $43.5(28)$ & $-10^{*}$ \\
\hline Roughead & 2003 & 13 & Postmeno women & High to low meat & $\mathrm{RCO}$ & -19 & $\mathrm{NTX} / \mathrm{Cr}$ & no & $3.77(0.33)^{*}$ & $3.88(0.33)^{*}$ & 11 \\
\hline Dawson- Hughes & 2004 & 32 & Adults $>50$ yrs & High vs low pro & $\mathrm{RCT}$ & & $\mathrm{NTX} / \mathrm{Cr}$ & no & $130(71)$ & $198(100)$ & $52^{*}$ \\
\hline Roughead & 2005 & 15 & Postmeno women & Milk to soy pro & $\mathrm{RCO}$ & -11 & $\mathrm{NTX} / \mathrm{Cr}$ & no & $3.08(0.24)^{*}$ & $3.20(0.24)^{*}$ & 15 \\
\hline Sakhaee & 2005 & 18 & Postmeno women & Kcitrate & $\mathrm{RCO}$ & 0 & $\mathrm{NT} / \mathrm{Cr}$ & no & $33(13)$ & $33(14)$ & 0.0 \\
\hline Sakhaee & 2005 & 18 & Postmeno women & Kcitrate & $\mathrm{RCO}$ & 0 & sCTX & yes & $0.54(0.32)$ & $0.49(0.29)$ & -9.3 \\
\hline Spence & 2005 & 15 & Postmeno women & Milk to soy pro & RCO & -2 & $\mathrm{NTX} / \mathrm{Cr}$ & no & $55.6(29.0)$ & $48(22.6)$ & -14 \\
\hline Kerstetter & 2006 & 20 & Women & Amt of soy & $\mathrm{RCO}$ & -29 & $\mathrm{NTx} / \mathrm{Cr}$ & yes & $52(27)$ & $48(13)$ & -7.7 \\
\hline Kerstetter & 2006 & 20 & Women & Soy versus meat & $\mathrm{RCO}$ & -24 & $\mathrm{NTx} / \mathrm{Cr}$ & yes & $64(36)$ & $48(13)$ & -25 \\
\hline Kerstetter & 2006 & 20 & Women & Amt of meat & $\mathrm{RCO}$ & -18 & $\mathrm{NT} / \mathrm{Cr}$ & yes & $51(36)$ & $64(36)$ & 25 \\
\hline Ceglia & 2008 & 19 & Adults $>50$ yrs & KHCO3 (high pro) & $\mathrm{RCT}$ & -57 & $\mathrm{NTX} / \mathrm{Cr}$ & no & $40.4(19.1)$ & $35.1(7.0)$ & -13 \\
\hline MacDonald & 2008 & 46 & Postmeno women & Kcitrate (high) & $\mathrm{RCT}$ & & $\mathrm{DPD} / \mathrm{Cr}$ & yes & $8.1(3.4)$ & $7.4(2.0)$ & -8.6 \\
\hline MacDonald & 2008 & 44 & Postmeno women & Kcitrate (low) & $\mathrm{RCT}$ & & $\mathrm{DPD} / \mathrm{Cr}$ & yes & $7.5(2.4)$ & $7.1(2.1)$ & -5.3 \\
\hline MacDonald & 2008 & 50 & Postmeno women & Ft \& veg & $\mathrm{RCT}$ & & $\mathrm{DPD} / \mathrm{Cr}$ & yes & $7.2(2.3)$ & $7.1(2.0)$ & -1.4 \\
\hline MacDonald & 2008 & 50 & Postmeno women & Kcitrate (high) & $\mathrm{RCT}$ & & sCTX & no & $0.21(0.11)$ & $0.20(0.11)$ & -4.3 \\
\hline MacDonald & 2008 & 51 & Postmeno women & Kcitrate (low) & $\mathrm{RCT}$ & & sCTX & no & $0.23(0.11)$ & $0.22(0.10)$ & -4.3 \\
\hline MacDonald & 2008 & 54 & Postmeno women & Ft \& veg & $\mathrm{RCT}$ & & sCTX & no & $0.20(0.13)$ & $0.21(0.11)$ & 5.0 \\
\hline Dawson- Hughes & 2009 & 162 & Adults $>50$ yrs & $\mathrm{K}$ or $\mathrm{Na} \mathrm{HCO} 3$ & $\mathrm{RCT}$ & -35 & $\mathrm{NTX} / \mathrm{Cr}$ & no & $38.8(17.2)$ & $33.7(13.9)$ & -13 \\
\hline Hunt & 2009 & 13 & Postmeno women & high to low pro (low Ca) & $\mathrm{RCO}$ & -24 & $\mathrm{DPD} / \mathrm{Cr}$ & yes & $2.3(0.2)^{*}$ & $2.4(0.2)^{*}$ & $15^{*}$ \\
\hline Hunt & 2009 & 14 & Postmeno women & high to low pro (High Ca) & $\mathrm{RCO}$ & -22 & $\mathrm{DPD} / \mathrm{Cr}$ & yes & $2.2(0.2)^{*}$ & $2.3(0.2)^{*}$ & $12^{*}$ \\
\hline Karp & 2009 & 12 & Women 20 - 30 years & Kcitrate & $\mathrm{RCO}$ & & $\mathrm{NTX} / \mathrm{Cr}$ & no & $23(12)$ & $16(10)^{*}$ & $-28^{*}$ \\
\hline
\end{tabular}

$\mathrm{DPD} / \mathrm{Cr}=$ urine deoxypyridinoline to creatinine ratio; $\mathrm{NTX} / \mathrm{Cr}=$ urine $\mathrm{N}$-telopeptide to creatinine ratio; $\mathrm{RCT}=$ random control trial; $\mathrm{RCO}=$ random cross-over study; pro $=$ protein, $\mathrm{s} C \mathrm{CTX}=$ serum $\mathrm{C}$-telopeptide, ${ }^{*}$ In transformed data 
[29]. Consequently, Hills criteria of strength of association is met if urine calcium is considered as the outcome, but not if whole body calcium balance is considered (Table 5).

\section{Hill's Criterion \#3: Biological Gradient}

The change in urine calcium may not represent a change in body calcium balance, and reporting the urine calcium without other measures of calcium flux 


\begin{tabular}{|c|c|c|c|c|c|c|c|c|c|c|}
\hline \multirow[b]{2}{*}{ Study or Subgroup } & \multicolumn{3}{|c|}{ Alkaline } & \multicolumn{3}{|c|}{ Control } & \multicolumn{3}{|c|}{ Std. Mean Difference } & \multirow{2}{*}{$\begin{array}{l}\text { Std. Mean Difference } \\
\text { IV, Random, } 95 \% \mathrm{CI}\end{array}$} \\
\hline & Mean & SD & Total & Mean & SD & Total & Weight & IV, Random, $95 \% \mathrm{CI}$ & Year & \\
\hline \multicolumn{11}{|l|}{ 3.1.1 Kerstetter 1999} \\
\hline $\begin{array}{l}\text { Kerstetter } 1999 \\
\text { Subtotal }(95 \% \mathrm{Cl})\end{array}$ & 48.2 & 29 & $\begin{array}{l}16 \\
16\end{array}$ & 43.5 & 28 & $\begin{array}{l}16 \\
16\end{array}$ & $\begin{array}{l}5.1 \% \\
5.1 \%\end{array}$ & $\begin{array}{c}0.16[-0.53,0.85] \\
0.16[-0.53,0.85]\end{array}$ & 1999 & \\
\hline \multicolumn{11}{|c|}{$\begin{array}{l}\text { Heterogeneity: Not applicable } \\
\text { Test for overall effect: } Z=0.45(P=0.65)\end{array}$} \\
\hline \multicolumn{11}{|l|}{ 3.1.2 Sakhaee 2005} \\
\hline $\begin{array}{l}\text { Sakhaee } 2005 \mathrm{sCTX} \\
\text { Subtotal }(95 \% \mathrm{CI})\end{array}$ & 0.54 & 0.32 & $\begin{array}{l}18 \\
18\end{array}$ & 0.49 & 0.29 & $\begin{array}{l}18 \\
18\end{array}$ & $\begin{array}{l}5.6 \% \\
5.6 \%\end{array}$ & $\begin{array}{c}0.16[-0.49,0.81] \\
\mathbf{0 . 1 6}[-0.49,0.81]\end{array}$ & 2005 & \\
\hline \multicolumn{11}{|c|}{ Heterogeneity: Not applicable } \\
\hline \multicolumn{11}{|l|}{ 3.1.3 Kerstetter 2006} \\
\hline Kerstetter 2006 Soy Meat & 52 & 26.9 & 20 & 48 & 13.4 & 20 & $6.0 \%$ & $0.18[-0.44,0.81]$ & 2006 & \\
\hline Kerstetter 2006 Meat & 51 & 36 & 20 & 64 & 36 & 20 & $6.0 \%$ & $-0.35[-0.98,0.27]$ & 2006 & \\
\hline $\begin{array}{l}\text { Kerstetter } 2006 \text { Soy } \\
\text { Subtotal }(95 \% \mathrm{Cl})\end{array}$ & 0.54 & 0.32 & $\begin{array}{l}18 \\
58\end{array}$ & 0.49 & 0.29 & $\begin{array}{l}18 \\
58\end{array}$ & $\begin{array}{r}5.6 \% \\
17.6 \%\end{array}$ & $\begin{array}{r}0.16[-0.49,0.81] \\
-0.01[-0.37,0.36]\end{array}$ & 2006 & \\
\hline \multicolumn{11}{|c|}{$\begin{array}{l}\text { Heterogeneity: } \text { Tau }^{2}=0.00 ; \mathrm{Chi}^{2}=1.80, \mathrm{df}=2(P=0.41) ; \mathrm{I}^{2}=0 \% \\
\text { Test for overall effect: } Z=0.04(P=0.97)\end{array}$} \\
\hline \multicolumn{11}{|l|}{ 3.1.4 MacDonald 2008} \\
\hline MacDonald Ft/veg CTX & 7.5 & 2.4 & 42 & 7.1 & 2.1 & 44 & $10.2 \%$ & $0.18[-0.25,0.60]$ & 2008 & \\
\hline MacDonald hi Kcitrate DPD & 0.2 & 0.11 & 47 & 0.21 & 0.11 & 50 & $10.9 \%$ & $-0.09[-0.49,0.31]$ & 2008 & \\
\hline MacDonald Ft/veg DPD & 0.21 & 0.11 & 47 & 0.2 & 0.13 & 54 & $11.1 \%$ & $0.08[-0.31,0.47]$ & 2008 & \\
\hline MacDonald lo Kcitrate CTX & 8.1 & 3.4 & 42 & 7.4 & 2 & 46 & $10.3 \%$ & $0.25[-0.17,0.67]$ & 2008 & \\
\hline MacDonald hi Kcitrate CTX & 7.2 & 2.3 & 42 & 7.1 & 2 & 50 & $10.5 \%$ & $0.05[-0.36,0.46]$ & 2008 & - \\
\hline $\begin{array}{l}\text { MacDonald lo Kcitrate DPD } \\
\text { Subtotal }(95 \% \mathrm{Cl})\end{array}$ & 0.22 & 0.1 & $\begin{array}{r}47 \\
267\end{array}$ & 0.23 & 0.11 & $\begin{array}{r}51 \\
295\end{array}$ & $\begin{array}{l}11.0 \% \\
63.9 \%\end{array}$ & $\begin{array}{r}-0.09[-0.49,0.30] \\
0.06[-0.11,0.22]\end{array}$ & 2008 & - \\
\hline \multicolumn{11}{|c|}{$\begin{array}{l}\text { Heterogeneity: } \mathrm{Tau}^{2}=0.00 ; \mathrm{Chi}^{2}=2.23, \mathrm{df}=5(P=0.82) ; \mathrm{I}^{2}=0 \% \\
\text { Test for overall effect: } Z=0.67(P=0.51)\end{array}$} \\
\hline \multicolumn{11}{|l|}{ 3.1.5 Hunt 2009} \\
\hline Hunt 2009 Low calcium & 9.3 & 1.2 & 14 & 10.4 & 1.2 & 14 & $4.2 \%$ & $-0.89[-1.67,-0.11]$ & 2009 & \\
\hline $\begin{array}{l}\text { Hunt } 2009 \text { High Calcium } \\
\text { Subtotal }(95 \% \mathrm{Cl})\end{array}$ & 10 & 1.2 & $\begin{array}{l}13 \\
27\end{array}$ & 11.5 & 1.2 & $\begin{array}{l}13 \\
27\end{array}$ & $\begin{array}{l}3.6 \% \\
7.8 \%\end{array}$ & $\begin{array}{l}-1.21[-2.06,-0.36] \\
-1.04[-1.61,-0.46]\end{array}$ & 2009 & \\
\hline \multicolumn{11}{|c|}{$\begin{array}{l}\text { Heterogeneity: } \mathrm{Tau}^{2}=0.00 ; \mathrm{Chi}^{2}=0.30, \mathrm{df}=1(P=0.59) ; \mathrm{I}^{2}=0 \% \\
\text { Test for overall effect: } Z=3.54(P=0.0004)\end{array}$} \\
\hline Total $(95 \% \mathrm{Cl})$ & & & 386 & & & 414 & $100.0 \%$ & $-0.03[-0.20,0.15]$ & & \\
\hline \multicolumn{7}{|c|}{$\begin{array}{l}\text { Heterogeneity: } \mathrm{Tau}^{2}=0.03 ; \mathrm{Chi}^{2}=17.70, \mathrm{df}=12(P=0.13) ;\left.\right|^{2}=32 \% \\
\text { Test for overall effect: } Z=0.31(P=0.76)\end{array}$} & & & & $\begin{array}{ccccc}-2 & -1 & 0 & 1 & 2 \\
\text { Favours control } & \text { Favours alkaline }\end{array}$ \\
\hline
\end{tabular}

(absorption [62], intestinal secretion [61], or fecal losses) may interfere with accurate interpretation. Methodologically superior calcium balance studies, which provide a more accurate assessment of whole body calcium metabolism compared to urine calcium, do not support the acid ash hypothesis [29].

Hill's criterion of causation regarding a Biological Gradient is substantiated by the evidence regarding urine calcium, but the evidence regarding calcium balance, the superior measure of whole body calcium metabolism does not support the acid ash hypothesis (Table 5).

\section{Hill's Criterion \#4: Plausibility}

Regarding Hill's plausibility criterion that a theory fit with current biological knowledge, the mechanism for diet acid load induced mineral resorption at the bone is not well described. Some researchers assert that bone is dissolved, releasing skeletal calcium and bicarbonate to neutralize the systemic acidemia $[9,113,127,133,134,221]$. Others hypothesize that the effect occurs at the kidney: calcium is lost in the urine as urinary bicarbonate is reabsorbed from the distal nephron to compensate for the excretion of anions. However, none of the in vitro studies supported these concepts since not one of these studies reported studies of bone demineralization or any adverse effects (such as activation of osteoclasts or enzymes) within the physiological range (7.35 to 7.45).

In contrast, the response to an alkaline diet on systemic $\mathrm{pH}$ in vivo has been documented in a randomized study to be $0.014 \mathrm{pH}$ units [14]. It has been proposed that the osteoclast cell secretes acid to dissolve mineral during the bone remodeling cycle [262] and it has been shown that osteoclast cells respond to changes in $\mathrm{pH}$ [103]. However, there is no evidence to support the 
Table 5 Summary Table of the Evaluation of the Acid-ash Hypothesis using Hill's Criteria

\begin{tabular}{|c|c|c|}
\hline Hill's criterion & $\begin{array}{l}\text { Is criterion } \\
\text { met? }\end{array}$ & Reason \\
\hline Temporality & $\begin{array}{l}\text { Yes, by inclusion } \\
\text { criteria }\end{array}$ & $\begin{array}{l}\text { Papers were included only if this Temporality criterion was met, that is the exposure preceded the } \\
\text { outcome. }\end{array}$ \\
\hline \multirow[t]{2}{*}{ Strength } & Yes & $\begin{array}{l}\text { Estimates of calcium loss in the urine are of sufficient magnitude to explain the progression of } \\
\text { osteoporosis, while calcium balance studies do not show support of the acid ash hypothesis. }\end{array}$ \\
\hline & No & \\
\hline $\begin{array}{l}\text { Biological Gradient or } \\
\text { Dose-response }\end{array}$ & No & $\begin{array}{l}\text { While urine calcium changes in response to changes in net acid excretion, calcium balance does not. } \\
\text { Calcium balance is a better measure of whole body calcium metabolism than urine calcium. }\end{array}$ \\
\hline \multirow[t]{2}{*}{ Biologically Plausible } & No & No defined mechanism that could take place at physiological pH. \\
\hline & No & $\begin{array}{l}\text { Problems with the hypothesis due to the incongruent roles of phosphate, sodium, and protein with } \\
\text { bone, and lack of support for the role of potassium. }\end{array}$ \\
\hline \multirow[t]{3}{*}{ Consistency } & No & $\begin{array}{l}\text { The prospective observational cohort studies have not consistently controlled for the key osteoporosis } \\
\text { risk factors, putting their findings into question. }\end{array}$ \\
\hline & No & The estimated effects of protein, milk and grain foods are not supported by evidence. \\
\hline & No & $\begin{array}{l}\text { The measurement of urinary acid excretion is not a precise science and measurements may be } \\
\text { inaccurate. }\end{array}$ \\
\hline \multirow[t]{3}{*}{ Experiments } & No & $\begin{array}{l}\text { The outcome measures used to date in experimental studies are only surrogate measures or correlates } \\
\text { of bone strength. The majority of experimental evidence supporting the acid-ash hypothesis is from } \\
\text { studies that used urine calcium and/or bone resorption markers as the outcomes, which are surrogate } \\
\text { measures of bone strength. }\end{array}$ \\
\hline & No & $\begin{array}{l}\text { The RCT that assessed changes of BMD with the lower risk of bias did not support the hypothesis. } \\
\text { Therefore, the experimental evidence does not support the hypothesis }\end{array}$ \\
\hline & No & $\begin{array}{l}\text { Meta-analyses of bone resorption markers in response to changes in acid and alkali loads did not } \\
\text { support the hypothesis whether all of the study results were combined or only studies that followed } \\
\text { recommendations for bone markers were assessed. }\end{array}$ \\
\hline
\end{tabular}

suggestion that the very small systemic $\mathrm{pH}$ changes $(<$ $0.02 \mathrm{pH}$ units) seen in response to diet [14] or possibly in response to bicarbonate salt changes actually influence the bone demineralization activities of osteoclasts cells or that diet acid becomes concentrated in the bone milieu. Further work is required to determine whether this is the case. Claims that these cell culture studies support the acid ash hypothesis are not supported by the evidence.

\section{Phosphate}

According to the acid-ash hypothesis, excess dietary "acid" from phosphate causes increased urine skeletal calcium excretion and loss of calcium, and the main source of dietary "acid" is dietary phosphate [152]. Meta-analyses of randomized studies of phosphate supplements did not see either of the hypothesis predicted effects of increased urine calcium and decreased calcium balance, and thus did not support the hypothesis regarding the role of phosphate.

\section{Protein}

According to the acid-ash hypothesis, higher dietary protein intakes are detrimental to bone health since protein is an important acid generating diet component and bone mineral is dissolved to neutralize acids and avoid systemic acidosis $[9,14-16]$. Increased calcium in the urine has been considered confirmation of this theoretical effect [15,18-21]. However, randomized trials of the amount $[57,62,67,69]$ and type (animal versus vegetable)
[59] of protein, and a meta-analyses of superior methodology randomized cross-over studies of protein intakes on calcium balance [29] do not support this proposed negative relationship between higher protein intakes and negative bone calcium retention.

Further, protein has positive effects on BMD, based on a meta-analysis of protein supplementation RCTs on spine BMD [27] and randomized trials that assessed the effect of protein after a hip fracture on BMD $[263,264]$. Therefore the assertion that higher protein intakes lead to osteoporosis is not upheld by the current evidence.

\section{Potassium}

Although seven randomized intervention studies reported decreased BR markers of nine [60,68] to 28 [72] percent in response to potassium salt ingestion $[58,60,65,68,70-72]$ the BR markers did not decrease by a sufficient magnitude $[46,47]$ to be considered to have made an important effect on bone resorption. The prospective observational study by Tucker at al. that found an association between potassium intakes and fruit and vegetable intakes with less BMD loss did not control for weight loss during follow-up, family history of osteoporosis, baseline BMD [75], and thus their finding could have been confounded by any of these osteoporosis risk factors. The three other observational studies did not find an association between potassium intakes and better bone health outcomes $[77,79,83]$. Therefore, the 
evidence does not support the acid-ash hypothesis tenet that potassium is bone protective.

\section{Protein and calcium interaction}

Some of the writers have suggested that calcium and protein work in an interaction such that protein is moreso or only detrimental to bone health when calcium intakes are low. The evidence to substantiate this assertion was limited to this single observational study [81], while one randomized trial did not support the idea [69]. Since the observational study that supported the idea that protein was detrimental to bone health when calcium intakes were low did not control for weight loss during follow-up, baseline BMD, and vitamin D status their finding may have been due to uncontrolled confounding. The randomized trial that examined the effect of two levels of calcium intake with two levels of protein intake revealed that protein was not detrimental to calcium balance whether calcium intakes were high or low. Thus the concept that higher protein intakes are detrimental to bone health when calcium intakes are low was not supported by the evidence.

In terms of the biological plausibility, the acid-ash hypothesis is not supported by research evidence regarding a mechanism that functions at physiological $\mathrm{pH}$ or the plausible roles of phosphate, sodium, potassium, protein, and a protein-calcium interaction in bone health (Table 5).

\section{Hill's Criterion \#5: Consistency}

To evaluate Hill's criterion regarding consistency which demands consistent evidence from a variety of study design elements to support a causal relationship, we examined the prospective observational studies on the acid ash hypothesis. Since three $[75,77,79]$ of the five prospective cohort studies that supported the hypothesis $[73,75,77,79,81]$ also had some findings (regarding some posited acid or alkaline nutrients) that did not support the hypothesis $[75,77,79]$, these studies did not demonstrate internal consistency in their support of the hypothesis. Further, several osteoporosis risk factors [49-52] were not controlled for in the hypothesis supporting cohort studies including: weight loss during follow-up $[74,75,81]$, parental history of osteoporosis [73-75,79], baseline BMD [73-75,77,81], vitamin D status $[74,75,77,79]$, and estrogen status [77] (Table 3). Due to the limitations of the observational study design and with the lack of control for important risk factors for osteoporosis, the prospective observational studies cannot clearly support a cause and effect relationship between diet derived acid and bone health. Thus, although quoted as proof of the acid-ash hypothesis, the prospective observational studies do not support the acid-ash hypothesis due to potential uncontrolled confounding by osteoporosis risk factors (Table 5).

\section{Hill's Criterion \#6: Experiment}

Hill's criterion regarding Experiment requires that actual experiments be conducted to determine whether the frequency of a disease is altered by an exposure [31]. To be able to claim causation, experimental evidence should demonstrate that the hypothesized exposure induces or prevents the disease under study. To our knowledge, neither of the direct measures of bone strength or osteoporosis (fragility fractures or bone strength as measured from bone biopsy samples) have been used as outcomes in randomized intervention trials of the acid-ash hypothesis.

\section{Changes in Bone Mineral Density}

Two randomized control trials have used changes of $\mathrm{BMD}$ as the outcome measure in post menopausal women with opposite findings $[65,68]$. A useful clinical measure of bone, BMD is not a direct measure of osteoporosis, but a surrogate measure of this disease. Changes of BMD are, therefore not ideal measures of osteoporosis. The two randomized control trials that measured changes of BMD as their outcome measures in studies of the acid ach hypothesis differed in quality by 2 important risks of Bias [43]: concealment of allocation and selective outcome reporting [65]. During the randomization process, when a study is designed to ensure that the randomization process is not tampered with, one can have more confidence that the study groups are equivalent in terms of known and unknown confounders. Concealing the allocation to the study groups by concealing the process, or making it unalterable by the investigators, is an indicator of study quality [43]. Thus the MacDonald et al study of potassium citrate and increased fruit and vegetable intakes on the change of BMD [65] was therefore considered the higher quality study. This study found no effect of the potassium citrate, or increased fruit and vegetable intakes on BMD over time [68], which is more likely to be an accurate reflection of the truth since it is less likely to be biased.

\section{Bone resorption markers (BR marker)}

The BR marker results did not support the acid-ash hypothesis. The inclusive analysis of the BR markers demonstrated significant heterogeneity by the more alkaline interventions, and thus suggests that the individual studies should not be combined. The finding of heterogeneity suggests that the various interventions (Table 1) to alter acid load, such as altering protein, fruit and vegetables intakes, or giving a bicarbonate or citrate salt are not equivalent, even though they are considered to be the same under the acid ash hypothesis. The sensitivity meta-analysis was sufficiently homogenous to proceed with meta-analysis, and the results revealed no significant difference in BR markers in response to a change in diet acid or alkaline load $(\mathrm{p}=$ 
0.76). The results from the one individual study that demonstrated a clinically important difference in the BR marker measured in fasting urine found that $\mathrm{N}$-telopeptide decreased in response to protein supplementation [58], a finding which is opposite direction to that which the hypothesis would predict. In summary, the BR marker results suggest no important changes in BR markers from an alkaline diet.

Thus, randomized controlled studies of the acid ash hypothesis using calcium balance, change of BMD, or BR markers do not support the hypothesis (Table 5).

\section{Discussion Overview}

This systematic review, based on quality randomized trials and prospective observational studies, did not find support for the acid-ash hypothesis which states that "acid" from the modern diet causes osteoporosis or that an alkaline diet or "alkaline" supplements or salts prevent osteoporosis. Applying Hill's criteria to this body of evidence provides additional insight into the likelihood of causality based on established criteria. The criterion related to the strength of association partially was met because the quantity of urine calcium was related to the diet acid load, however, calcium balance which is the preferred measure of calcium metabolism, was not related to diet acid load. The criteria for the biological gradient, biologic plausibility, consistency and experimental evidence for a casual relationship for the acid ash hypothesis were lacking with regard to whole body calcium balance, bone resorption markers, and changes in BMD. Thus, claims that the modern "acid" producing diet causes osteoporosis were not substantiated by research evidence. These finding suggest there is not likely any bone health benefit from consumption of commercial products intended to counteract this dietary acid.

Hill's criterion requires consistent evidence from a variety of experimental designs and the studies of food estimates of acid load remain inconsistent and show only associations with urine calcium rather than a causal relationship for osteoporosis. Although there is general agreement in the commercial literature and advertising about which foods contribute acid and base, the foundation of these statements is weak and it is unclear whether the calculated amounts of acid or base have any association with health or disease.

In addressing these findings within the context of the existing acid-ash hypothesis, limitations to the evidence can be identified. Evidence or limitations to the evidence arise in the following areas: 1) lack of support for the hypothesis by well-designed calcium balance studies; 2) lack of well-designed studies with more direct measures of this disease (bone strength as measured by fragility fractures or biomechanical testing of bone biopsy material); 3) lack of control of important potential risk factors among the longitudinal cohort studies; and 4) lack of a defined mechanism that could occur at physiological $\mathrm{pH}$. Small alterations in the surrogate measures of calcium in the urine and/or changes in BR markers are not evidence that alterations in the diet acid load cause bone demineralization. Additionally biological plausibility is questionable because of the conflicting roles of phosphate, sodium, potassium, protein and calcium interactions, and milk, since the roles put forth by the hypothesis differ from the actual roles of these molecules with respect to osteoporosis.

In the acid-ash model, sodium is one of the cations that has been assumed to represent base excretion, and cations theoretically protect against bone calcium losses [15]. In the model of the acid-ash hypothesis, sodium is considered to have a similar bone protective effect to calcium, potassium, and magnesium. However, experts consider high sodium intakes to be a possible risk factor for bone mineral loss [48]. It is possible that the acidash hypothesis is over simplistic in its categorization of sodium, potassium, calcium and magnesium as protective ions vis-à-vis bone health.

Early work to define food sources of acid and base began early in the previous century $[110,112,265]$. Sherman published tables listing the acid and base contributions of 64 foods based on the ashed foods' mineral content in 1912 [110]. Remer and Manz updated the original calculation in 1995 when they published newer tables of food acid loads with simple correction factors for each mineral designed to take imperfect absorption into account [152]. The 1912 and 1995 food lists share a premise that urinary excretion of hydroxides of sodium, potassium, calcium and magnesium reflect "base" excretion while urinary protonated forms of phosphate, sulfate, and chloride reflect "acid" excretion $[110,152,265]$. However, the assumption that food lists can reliably and exclusively classify foods as dietary sources of excreted acid or base is not supported by this review. The food lists categorize dietary phosphate and protein containing foods as acid sources anticipated to enhance bone loss, while evidence suggests that dietary phosphate does not increase calcium excretion (Figure 4) or decrease calcium balance (Figure 5), and dietary protein may enhance or protect BMD $[263,264]$. Although Remer and Manz estimated that milk has a slight acidic load [152], other investigators estimated that milk would supply an alkaline load $[110,122]$, and a recent study revealed that milk actually contributes an alkaline load [207]. Grains were included in the food lists as acid generating, and have been considered "acid-yielding" [17], but have not been evaluated for their hypothesized acidogenic and calciuric responses or effect on bone health, although two attempts have been made [133,197]. 
The measurement of the diet acid load based on urine titratable acidity, ammonia and bicarbonate $[14,15,115]$ is not a precise estimate due to problems with each constituent [24]. Ammonium (as ammonia) and bicarbonate (as $\mathrm{CO}_{2}$ ) may be lost due to volatility [266] prior to their measurement. Additionally, the measurement of titratable acidity is influenced by poor solubility of calcium, phosphorus, and uric acid, which can cause an over or underestimation of titratable acidity [24,267]. Therefore the measurement of urinary acid excretion is error prone and may not accurately reflect the exposure to dietary acidity.

The majority of experimental evidence supporting the acid-ash hypothesis is derived from studies that have used urine calcium and/or BR markers as the outcome measure. Urine calcium changes are confounded by changes in calcium absorption. The estimated change in BR markers (Figures 6 \&7) is less than the "least significant change" needed to consider that a true biological effect has occurred as opposed to a change due to measurement error $[46,47,268]$ and the results are inconsistent. The better-designed RCT which used changes of BMD as the outcome did not support the hypothesis [68]. The lack of consistent information regarding the effects of protein, milk and grain foods on bone undermines support for the acid-ash hypothesis, and the unreliable measurement of acid excretion in urine further undermines the hypothesis (Table 5). Therefore, the experimental evidence does not support the acid-ash hypothesis (Table 5).

The acid-ash hypothesis recommends that to maintain bone health people consume generous quantities of fruit and vegetables ( 8 to 10 servings per day $[145,152,242]$ ) along with modest amounts of grain and protein foods $[21,42]$. Generous quantities of fruit and vegetables are not likely to be harmful and may have other health benefits [269]. It is possible that fruit and vegetables are beneficial to bone health through mechanisms other than via the acid-ash hypothesis since there is some preliminary human and animal evidence that some fruits and some vegetables have supportive effects on bone $[270,271]$.

In contrast to the acid-ash hypothesis, recent research suggests that sufficient protein intake is needed for the maintenance of bone integrity [27,29,62,263,263,264]. Changes in urine calcium and BR markers should not be considered proof of the acid-ash hypothesis.

\section{Strengths and Limitations}

The primary strengths of this study are that we conducted a broad search of the literature, only included studies with randomized or prospective cohort study designs, and focused on the higher quality randomized studies, evaluated these studies for risk of bias, as recommended for systematic reviews [36]. We recognize the limitation of a systematic review is that the conclusions are based on the available studies. To formally reject the acid-ash hypothesis, well-designed unbiased studies with adequate rigor [34-36,36] are needed, using direct measures for osteoporosis bone fragility: biomechanical testing of bone or the incidence of fragility fractures [259,260].

\section{Conclusions}

Based on the review of the literature to date and an application of Hill's criteria to the evidence the relationship between dietary acid with risk of osteoporosis is not confirmed. Further research is needed to determine whether fruit and/or vegetables are protective of bone health and what are the ideal protein intakes for bone health.

\section{Funding}

This work was supported in part by: Doctoral fellowships from the University of Calgary and the Alberta Heritage Fund for Medical Research. The funders played no role in study design, collection, analysis, interpretation of data, writing of the report, or the conclusions reached.

\section{Abbreviations}

BMD: Bone mineral density; BR markers: bone resorption markers; $\mathrm{Cl}$ : confidence interval; CTX: C-telopeptide; DPD: deoxypyridinoline; NAE: net acid excretion; RCT: randomized controlled trial;

\section{Acknowledgements}

We thank Diane Lorenzetti MLS for assistance with the literature search strategy and Genevieve Zimantas for editorial assistance.

\section{Author details}

${ }^{1}$ Department of Community Health Sciences, University of Calgary, Calgary, AB, Canada. ${ }^{2}$ Nutrition Services, Alberta Health Services, Calgary, AB, Canada. ${ }^{3}$ Department of Pathology \& Laboratory Medicine, University of Calgary, Calgary, AB, Canada. ${ }^{4}$ Calgary Laboratory Services, Calgary AB, Canada. ${ }^{5}$ Department of Medicine and Oncology, University of Calgary, Calgary, AB, Canada.

\section{Authors' contributions}

The author's responsibilities were as follows: TRF, SCT, \& AWL designed the study, TRF, SCT, AWL \& DAH extracted the data; TRF searched the literature, performed the statistical analysis and wrote the manuscript. ME directed the study's statistical analysis and graphic representations, SCT and TRF

independently rated the randomized studies for their risk of bias using the Cochrane Risk of Bias Tool. All of the authors contributed to interpret the findings and writing the manuscript, and all authors read and approved the final manuscript.

\section{Competing interests}

The authors declare that they have no competing interests.

Received: 11 August 2010 Accepted: 30 April 2011

Published: 30 April 2011

\section{References}

1. Energize for Life. [http://www.energiseforlife.com/cat-AlkalisingSupplements-ALKALISING_SUPPLEMENTS.html]. 
2. Acid-2-Alkaline. [http://www.alkalinebodybalance.com/].

3. Beginning an Alkaline Diet. [http://ezinearticles.com/?Beginning-anAlkaline-Diet:-The-Basic-Principles-Start-Alkalizing-Today!\&id=59925].

4. Alkaline Diet Guy: Alkaline Food or Acid Food-Why should I care? [http://www.kewego.co.uk/video/iLyROoafMHPI.html].

5. Brown SE: Better bones, Better body. 2 edition. Columbus: McGraw Hill; 2000.

6. Young RO: The pH Miracle: Balance your Diet, reclaim your health New York: Grand Central Publishers; 2003.

7. Vasey C: Acid Alkaline Diet Rochester: Healing Arts Press; 2006

8. Graci S: The Bone Building Solution Toronto, Canada: John Wiley \& sons; 2006.

9. Sebastian A, Harris ST, Ottaway JH, Todd KM, Morris RC Jr: Improved mineral balance and skeletal metabolism in postmenopausal women treated with potassium bicarbonate. N Engl J Med 1994, 330:1776-1781.

10. New SA: Nutrition Society Medal lecture. The role of the skeleton in acid-base homeostasis. Proc Nutr Soc 2002, 61:151-164.

11. DuBose TD: Acid-base disorders. In Brenner \& Rector's The Kidney.. 6 edition. Edited by: Brenner BM. Saunders; 2000:935-937.

12. Institute of Medicine (IOM): Dietary Reference Intakes for Water, Potassium, Sodium, Chloride, and Sulfate Washington DC: The National Academies Press; 2004.

13. Burns L, Ashwell M, Berry J, Bolton-Smith C, Cassidy A, Dunnigan M, Khaw KT, Macdonald H, New S, Prentice A, Powell J, Reeve J, Robins S, Teucher B: UK Food Standards Agency Optimal Nutrition Status Workshop: environmental factors that affect bone health throughout life. Br J Nutr 2003, 89:835-840.

14. Buclin T, Cosma M, Appenzeller M, Jacquet AF, Decosterd LA, Biollaz J, Burckhardt P: Diet acids and alkalis influence calcium retention in bone. Osteoporos Int 2001, 12:493-499.

15. Remer T, Manz F: Estimation of the renal net acid excretion by adults consuming diets containing variable amounts of protein. Am J Clin Nutr 1994, 59:1356-1361.

16. New SA: Intake of fruit and vegetables: implications for bone health. Proc Nutr Soc 2003, 62:889-899.

17. Konner M, Eaton SB: Paleolithic nutrition: twenty-five years later. Nutr Clin Pract 2010, 25:594-602.

18. Schuette SA, Zemel MB, Linkswiler HM: Studies on the mechanism of protein-induced hypercalciuria in older men and women. J Nutr 1980, 110:305-315

19. Manz F, Remer T, Decher-Spliethoff E, Hohler M, Kersting M, Kunz C, Lausen B: Effects of a high protein intake on renal acid excretion in bodybuilders. Z Ernahrungswiss 1995, 34:10-15.

20. Breslau NA, Brinkley L, Hill KD, Pak CY: Relationship of animal protein-rich diet to kidney stone formation and calcium metabolism. J Clin Endocrinol Metab 1988, 66:140-146.

21. Ince BA, Anderson EJ, Neer RM: Lowering dietary protein to U.S. Recommended dietary allowance levels reduces urinary calcium excretion and bone resorption in young women. J Clin Endocrinol Metab 2004, 89:3801-3807.

22. Camien MN, Simmons DH, Gonick HC: A critical reappraisal of "acid-base" balance. Am J Clin Nutr 1969, 22:786-793.

23. Dwyer J, Foulkes E, Evans M, Ausman L: Acid/alkaline ash diets: time for assessment and change. J Am Diet Assoc 1985, 85:841-845.

24. Oh MS: New perspectives on acid-base balance. Semin Dial 2000, 13:212-219.

25. Mioni R, Sala P, Mioni G: [Nutrition, acid-base metabolism, cation-anion difference and total base balance in humans]. G Ital Nefrol 2008, 25:407-421.

26. Bonjour JP: Dietary protein: an essential nutrient for bone health. J Am Coll Nutr 2005, 24:526S-536S.

27. Darling AL, Millward DJ, Torgerson DJ, Hewitt CE, Lanham-New SA: Dietary protein and bone health: a systematic review and meta-analysis. Am J Clin Nutr 2009, 90:1674-1692.

28. Fenton TR, Lyon AW, Eliasziw M, Tough SC, Hanley DA: Phosphate decreases urine calcium and increases calcium balance: A meta-analysis of the osteoporosis acid-ash diet hypothesis. Nutr J 2009, 8:41.

29. Fenton TR, Lyon AW, Eliasziw M, Tough SC, Hanley DA: Meta-analysis of the effect of the acid-ash hypothesis of osteoporosis on calcium balance. J Bone Miner Res 2009, 24:1835-1840.

30. Ashwell M, Stone E, Mathers J, Barnes S, Compston J, Francis RM, Key T, Cashman KD, Cooper C, Khaw KT, Lanham-New S, Macdonald H, Prentice A,
Shearer M, Stephen A: Nutrition and bone health projects funded by the UK Food Standards Agency: have they helped to inform public health policy? Br J Nutr 2008, 99:198-205.

31. Hill AB: The environment and disease: Association or causation? Proc $R$ Soc Med 1965, 58:295-300.

32. Hennekens $\mathrm{CH}$, Buring JE: Statistical concepts. Epidemiology in Medicine Boston: Little, Brown and Company; 1987.

33. Rothman KJ, Greenland S: Causation and causal inference. In Modern Epidemiology.. 2 edition. Edited by: Rothman KJ, Greenland S. Philadelphia: Lippincott Williams 1998:7-28.

34. Moher D, Pham B, Jones A, Cook DJ, Jadad AR, Moher M, Tugwell P, Klassen TP: Does quality of reports of randomised trials affect estimates of intervention efficacy reported in meta-analyses? Lancet 1998, 352:609-613.

35. Schulz KF, Chalmers I, Hayes RJ, Altman DG: Empirical evidence of bias. Dimensions of methodological quality associated with estimates of treatment effects in controlled trials. JAMA 1995, 273:408-412.

36. Wood L, Egger M, Gluud LL, Schulz KF, Juni P, Altman DG, Gluud C, Martin RM, Wood AJ, Sterne JA: Empirical evidence of bias in treatment effect estimates in controlled trials with different interventions and outcomes: meta-epidemiological study. BMJ 2008, 336:601-605.

37. Liberati A, Altman DG, Tetzlaff J, Mulrow C, Gotzsche PC, loannidis JP, Clarke M, Devereaux PJ, Kleijnen J, Moher D: The PRISMA statement for reporting systematic reviews and meta-analyses of studies that evaluate health care interventions: explanation and elaboration. J Clin Epidemiol 2009, 62:e1-34.

38. NIH Consensus Development Panel: Osteoporosis prevention, diagnosis, and therapy. JAMA 2001, 285:785-795.

39. Institute of Medicine (IOM): Dietary Reference Intakes for calcium, phosphorus, magnesium, vitamin D and fluoride Washington DC: The National Academies Press; 1997.

40. Aschengrau A, Seage GR: Confounding. Essentials of Epidemiology in Public Health Sudbury MA: Jones and Bartlett Publishers; 2003, 281-289.

41. Last JM: A Dictionary of Epidemiology. 4 edition. New York, NY: Oxford University Press; 2001.

42. Institute of Medicine (IOM): Dietary Reference Intakes for Energy, Carbohydrate, Fiber, Fat, Fatty Acids, Cholesterol, Protein, and Amino Acids (Macronutrients) Washington DC: The National Academies Press; 2002.

43. Cochrane Handbook for Systematic Reviews of Interventions. 5.0.2 edition. The Cochrane Collaboration; 2009.

44. Rosner B: Design and techniques for epidemiologic studies. Fundamentals of Biostatistics. 5 edition. Pacific Grove, CA: Duxbury; 2000, 577-676.

45. Herrmann M, Seibel MJ: The amino- and carboxyterminal cross-linked telopeptides of collagen type I, NTX-I and CTX-I: a comparative review. Clin Chim Acta 2008, 393:57-75.

46. Brown JP, Albert C, Nassar BA, Adachi JD, Cole D, Davison KS, Dooley KC, Don-Wauchope A, Douville P, Hanley DA, Jamal SA, Josse R, Kaiser S, Krahn J, Krause R, Kremer R, Lepage R, Letendre E, Morin S, Ooi DS, Papaioaonnou A, Ste-Marie LG: Bone turnover markers in the management of postmenopausal osteoporosis. Clin Biochem 2009, 42:929-942.

47. Bergmann P, Body JJ, Boonen S, Boutsen Y, Devogelaer JP, Goemaere S, Kaufman JM, Reginster JY, Gangji V: Evidence-based guidelines for the use of biochemical markers of bone turnover in the selection and monitoring of bisphosphonate treatment in osteoporosis: a consensus document of the Belgian Bone Club. Int J Clin Pract 2009, 63:19-26.

48. Brown JP, Josse RG: 2002 clinical practice guidelines for the diagnosis and management of osteoporosis in Canada. CMAJ 2002, 167:S1-34.

49. Ensrud KE, Cauley J, Lipschutz R, Cummings SR: Weight change and fractures in older women. Study of Osteoporotic Fractures Research Group. Arch Intern Med 1997, 157:857-863.

50. Kanis JA, Johansson $H$, Oden A, Johnell O, De Laet C, Eisman JA, McCloskey EV, Mellstrom D, Melton LJ, Pols HA, Reeve J, Silman AJ, Tenenhouse A: A family history of fracture and fracture risk: a metaanalysis. Bone 2004, 35:1029-1037.

51. Marshall D, Johnell O, Wedel H: Meta-analysis of how well measures of bone mineral density predict occurrence of osteoporotic fractures. BMJ 1996, 312:1254-1259.

52. MacLean C, Newberry S, Maglione M, McMahon M, Ranganath V, Suttorp M, Mojica W, Timmer M, Alexander A, McNamara M, Desai SB, Zhou A, Chen S, Carter J, Tringale C, Valentine D, Johnsen B, Grossman J: Systematic review: 
comparative effectiveness of treatments to prevent fractures in men and women with low bone density or osteoporosis. Ann Intern Med 2008, 148:197-213.

53. Patton MB, Wilson ED, Leichsenring JM, Norris LM, Dienhart CM: The relation of calcium-to-phosphorus ratio to the utilization of these minerals by 18 young college women. J Nutr 1953, 50:373-382.

54. Whybro A, Jagger H, Barker M, Eastell R: Phosphate supplementation in young men: lack of effect on calcium homeostasis and bone turnover. Eur J Clin Nutr 1998, 52:29-33.

55. Dahl WJ, Whiting SJ, Stephen AM: Dietary lentils and calcium balance in adult men. Nutrition Research 1995, 15:1587-1598.

56. Kerstetter JE, Mitnick ME, Gundberg CM, Caseria DM, Ellison AF, Carpenter TO, Insogna $\mathrm{KL}$ : Changes in bone turnover in young women consuming different levels of dietary protein. J Clin Endocrinol Metab 1999, 84:1052-1055.

57. Roughead ZK, Johnson LK, Lykken Gl, Hunt JR: Controlled high meat diets do not affect calcium retention or indices of bone status in healthy postmenopausal women. J Nutr 2003, 133:1020-1026.

58. Dawson-Hughes B, Harris SS, Rasmussen H, Song L, Dallal GE: Effect of dietary protein supplements on calcium excretion in healthy older men and women. J Clin Endocrinol Metab 2004, 89:1169-1173.

59. Roughead ZK, Hunt JR, Johnson LK, Badger TM, Lykken Gl: Controlled substitution of soy protein for meat protein: effects on calcium retention, bone, and cardiovascular health indices in postmenopausal women. J Clin Endocrinol Metab 2005, 90:181-189.

60. Sakhaee K, Maalouf NM, Abrams SA, Pak CY: Effects of potassium alkali and calcium supplementation on bone turnover in postmenopausal women. J Clin Endocrinol Metab 2005, 90:3528-3533.

61. Spence LA, Lipscomb ER, Cadogan J, Martin B, Wastney ME, Peacock M, Weaver CM: The effect of soy protein and soy isoflavones on calcium metabolism in postmenopausal women: a randomized crossover study. Am J Clin Nutr 2005, 81:916-922.

62. Kerstetter JE, O'Brien KO, Caseria DM, Wall DE, Insogna KL: The impact of dietary protein on calcium absorption and kinetic measures of bone turnover in women. J Clin Endocrinol Metab 2005, 90:26-31.

63. Frassetto L, Morris RC Jr, Sebastian A: Long-term persistence of the urine calcium-lowering effect of potassium bicarbonate in postmenopausal women. J Clin Endocrinol Metab 2005, 90:831-834.

64. Gettman MT, Ogan K, Brinkley LJ, Adams-Huet B, Pak CY, Pearle MS: Effect of cranberry juice consumption on urinary stone risk factors. J Urol 2005 174:590-594.

65. Jehle S, Zanetti A, Muser J, Hulter HN, Krapf R: Partial neutralization of the acidogenic Western diet with potassium citrate increases bone mass in postmenopausal women with osteopenia. J Am Soc Nephrol 2006, 17:3213-3222.

66. Kemi VE, Karkkainen MU, Lamberg-Allardt CJ: High phosphorus intakes acutely and negatively affect $\mathrm{Ca}$ and bone metabolism in a dosedependent manner in healthy young females. Br J Nutr 2006, 96:545-552.

67. Kerstetter JE, Wall DE, O'Brien KO, Caseria DM, Insogna KL: Meat and soy protein affect calcium homeostasis in healthy women. J Nutr 2006, 136:1890-1895.

68. Macdonald HM, Black AJ, Aucott L, Duthie G, Duthie S, Sandison R, Hardcastle AC, Lanham New SA, Fraser WD, Reid DM: Effect of potassium citrate supplementation or increased fruit and vegetable intake on bone metabolism in healthy postmenopausal women: a randomized controlled trial. Am J Clin Nutr 2008, 88:465-474

69. Hunt JR, Johnson LK, Fariba Roughead ZK: Dietary protein and calcium interact to influence calcium retention: a controlled feeding study. Am J Clin Nutr 2009, 89:1357-1365.

70. Ceglia L, Harris SS, Abrams SA, Rasmussen HM, Dallal GE, Dawson-Hughes B: Potassium bicarbonate attenuates the urinary nitrogen excretion that accompanies an increase in dietary protein and may promote calcium absorption. J Clin Endocrinol Metab 2009, 94:645-653.

71. Dawson-Hughes B, Harris SS, Palermo NJ, Castaneda-Sceppa C, Rasmussen HM, Dallal GE: Treatment with potassium bicarbonate lowers calcium excretion and bone resorption in older men and women. $J$ Clin Endocrinol Metab 2009, 94:96-102.

72. Karp HJ, Ketola ME, Lamberg-Allardt CJ: Acute effects of calcium carbonate, calcium citrate and potassium citrate on markers of calcium and bone metabolism in young women. Br J Nutr 2009, 102:1341-1347.
73. Feskanich D, Willett WC, Stampfer MJ, Colditz GA: Protein consumption and bone fractures in women. Am J Epidemiol 1996, 143:472-479.

74. Munger RG, Cerhan JR, Chiu BC: Prospective study of dietary protein intake and risk of hip fracture in postmenopausal women. Am J Clin Nutr 1999, 69:147-152.

75. Tucker KL, Hannan MT, Kiel DP: The acid-base hypothesis: diet and bone in the Framingham Osteoporosis Study. Eur J Nutr 2001, 40:231-237.

76. Promislow JH, Goodman-Gruen D, Slymen DJ, Barrett-Connor E: Protein consumption and bone mineral density in the elderly: the Rancho Bernardo Study. Am J Epidemiol 2002, 155:636-644.

77. Kaptoge S, Welch A, McTaggart A, Mulligan A, Dalzell N, Day NE, Bingham S, Khaw KT, Reeve J: Effects of dietary nutrients and food groups on bone loss from the proximal femur in men and women in the 7th and 8th decades of age. Osteoporos Int 2003, 14:418-428.

78. Rapuri PB, Gallagher JC, Haynatzka V: Protein intake: effects on bone mineral density and the rate of bone loss in elderly women. Am J Clin Nutr 2003, 77:1517-1525.

79. Macdonald HM, New SA, Golden MH, Campbell MK, Reid DM: Nutritional associations with bone loss during the menopausal transition: evidence of a beneficial effect of calcium, alcohol, and fruit and vegetable nutrients and of a detrimental effect of fatty acids. Am J Clin Nutr 2004, 79:155-165.

80. Thorpe DL, Knutsen SF, Beeson WL, Rajaram S, Fraser GE: Effects of meat consumption and vegetarian diet on risk of wrist fracture over 25 years in a cohort of peri- and postmenopausal women. Public Health Nutr 2008, 11:564-572.

81. Dargent-Molina P, Sabia S, Touvier M, Kesse E, Breart G, Clavel-Chapelon F, Boutron-Ruault MC: Proteins, dietary acid load, and calcium and risk of postmenopausal fractures in the E3N French women prospective study. J Bone Miner Res 2008, 23:1915-1922.

82. Pedone C, Napoli N, Pozzilli P, Lauretani F, Bandinelli S, Ferrucci L, AntonelliInc: Quality of diet and potential renal acid load as risk factors for reduced bone density in elderly women. Bone 2009.

83. Fenton TR, Eliasziw M, Lyon AW, Tough SC, Brown JP, Hanley DA: Low urine $\mathrm{pH}$ and acid excretion do not predict bone fractures or the loss of bone mineral density: a prospective cohort study. BMC Musculoskeletal Disorders 2010, 11:88

84. Beasley JM, Ichikawa LE, Ange BA, Spangler L, LaCroix AZ, Ott SM, Scholes D: Is protein intake associated with bone mineral density in young women? Am J Clin Nutr 2010, 91:1311-1316.

85. Bushinsky DA, Krieger NS, Geisser DI, Grossman EB, Coe FL: Effects of pH on bone calcium and proton fluxes in vitro. Am J Physiol 1983, 245: F204-F209.

86. Bushinsky DA, Lechleider RJ: Mechanism of proton-induced bone calcium release: calcium carbonate-dissolution. Am J Physiol 1987, 253:F998-1005.

87. Bushinsky DA, Sessler NE, Krieger NS: Greater unidirectional calcium efflux from bone during metabolic, compared with respiratory, acidosis. Am J Physiol 1992, 262:F425-F431.

88. Krieger NS, Sessler NE, Bushinsky DA: Acidosis inhibits osteoblastic and stimulates osteoclastic activity in vitro. Am J Physiol 1992, 262:F442-F448.

89. Carano A, Schlesinger PH, Athanasou NA, Teitelbaum SL, Blair HC: Acid and base effects on avian osteoclast activity. Am J Physiol 1993, 264: c694-C701.

90. Bushinsky DA, Wolbach W, Sessler NE, Mogilevsky R, Levi-Setti R: Physicochemical effects of acidosis on bone calcium flux and surface ion composition. J Bone Miner Res 1993, 8:93-102.

91. Sprague SM, Krieger NS, Bushinsky DA: Greater inhibition of in vitro bone mineralization with metabolic than respiratory acidosis. Kidney Int 1994, 46:1199-1206.

92. Bushinsky DA, Sessler NE, Glena RE, Featherstone JD: Proton-induced physicochemical calcium release from ceramic apatite disks. J Bone Miner Res 1994, 9:213-220.

93. Arnett TR, Boyde A, Jones SJ, Taylor ML: Effects of medium acidification by alteration of carbon dioxide or bicarbonate concentrations on the resorptive activity of rat osteoclasts. J Bone Miner Res 1994, 9:375-379.

94. Arnett TR, Spowage M: Modulation of the resorptive activity of rat osteoclasts by small changes in extracellular $\mathrm{pH}$ near the physiological range. Bone 1996, 18:277-279.

95. Krieger NS, Parker WR, Alexander KM, Bushinsky DA: Prostaglandins regulate acid-induced cell-mediated bone resorption. Am J Physiol Renal Physiol 2000, 279:F1077-F1082. 
96. Meghji S, Morrison MS, Henderson B, Arnett TR: pH dependence of bone resorption: mouse calvarial osteoclasts are activated by acidosis. Am J Physiol Endocrinol Metab 2001, 280:E112-E119.

97. Disthabanchong S, Martin KJ, McConkey CL, Gonzalez EA: Metabolic acidosis up-regulates PTH/PTHrP receptors in UMR 106-01 osteoblastlike cells. Kidney Int 2002, 62:1171-1177.

98. Frick KK, Bushinsky DA: Metabolic acidosis stimulates RANKL RNA expression in bone through a cyclo-oxygenase-dependent mechanism. $J$ Bone Miner Res 2003, 18:1317-1325.

99. Brandao-Burch A, Utting JC, Orriss IR, Arnett TR: Acidosis inhibits bone formation by osteoblasts in vitro by preventing mineralization. Calcif Tissue Int 2005, 77:167-174.

100. Frick KK, LaPlante K, Bushinsky DA: RANK ligand and TNF-alpha mediate acid-induced bone calcium efflux in vitro. Am J Physiol Renal Physiol 2005, 289:F1005-F1011.

101. Krieger NS, Frick KK, LaPlante SK, Michalenka A, Bushinsky DA: Regulation of COX-2 mediates acid-induced bone calcium efflux in vitro. J Bone Miner Res 2007, 22:907-917

102. Nielsen RH, Karsdal MA, Sorensen MG, Dziegiel MH, Henriksen K: Dissolution of the inorganic phase of bone leading to release of calcium regulates osteoclast survival. Biochem Biophys Res Commun 2007, 360:834-839

103. Arnett TR: Extracellular pH regulates bone cell function. J Nutr 2008, 138:415S-4185.

104. Kaneko K, Masaki U, Aikyo M, Yabuki K, Haga A, Matoba C, Sasaki H, Koike G: Urinary calcium and calcium balance in young women affected by high protein diet of soy protein isolate and adding sulfur-containing amino acids and/or potassium. J Nutr Sci Vitaminol (Tokyo) 1990, 36:105-116.

105. Shapses SA, Robins SP, Schwartz El, Chowdhury H: Short-term changes in calcium but not protein intake alter the rate of bone resorption in healthy subjects as assessed by urinary pyridinium cross-link excretion. $J$ Nutr 1995, 125:2814-2821.

106. Shohl AT, Sato A: Acid-base metabolism: Determination of base balance. J Biol Chem 1923, 58:235-255.

107. Cole DE, Zlotkin SH: Increased sulfate as an etiological factor in the hypercalciuria associated with total parenteral nutrition. Am J Clin Nutr 1983, 37:108-113.

108. Sulyok E: Effect of $\mathrm{NH} 4 \mathrm{Cl}$-induced metabolic acidosis on urinary calcium excretion in young infants. Acta Paediatr Acad Sci Hung 1977, 18:103-112.

109. Lemann J Jr, Gray RW, Maierhofer WJ, Cheung HS: The importance of renal net acid excretion as a determinant of fasting urinary calcium excretion. Kidney Int 1986, 29:743-746.

110. Sherman HC, Gettler AO: The balance of acid-forming and base-forming elements in foods, and its relation to ammonia metabolism. J Biol Chem 1912, 11:323-338.

111. Draper HH, Piche LA, Gibson RS: Effects of a high protein intake from common foods on calcium metabolism in a cohort of postmenopausal women. Nutr Res 1991, 11:273-281.

112. Blatherwick NR: The specific role of food in relation to the composition of the urine. Arch Intern Med 1914, 409-450.

113. Marangella M, Di Stefano M, Casalis S, Berutti S, D'Amelio P, Isaia GC: Effects of potassium citrate supplementation on bone metabolism. Calcif Tissue Int 2004, 74:330-335.

114. Weber HP, Gray RW, Dominguez JH, Lemann I Jr: The lack of effect of chronic metabolic acidosis on $25-\mathrm{OH}$-vitamin $\mathrm{D}$ metabolism and serum parathyroid hormone in humans. J Clin Endocrinol Metab 1976, 43:1047-1055.

115. Lutz J, Linkswiler HM: Calcium metabolism in postmenopausal and osteoporotic women consuming two levels of dietary protein. Am J Clin Nutr 1981, 34:2178-2186.

116. Schuette SA, Linkswiler HM: Effects on Ca and P metabolism in humans by adding meat, meat plus milk, or purified proteins plus $\mathrm{Ca}$ and $\mathrm{P}$ to a low protein diet. I Nutr 1982, 112:338-349.

117. Lutz J: Calcium balance and acid-base status of women as affected by increased protein intake and by sodium bicarbonate ingestion. $\mathrm{Am} J \mathrm{Clin}$ Nutr 1984, 39:281-288.

118. Lewis NM, Marcus MS, Behling AR, Greger JL: Calcium supplements and milk: effects on acid-base balance and on retention of calcium, magnesium, and phosphorus. Am J Clin Nutr 1989, 49:527-533.
119. Jenkins DJ, Kendall CW, Vidgen E, Augustin LS, Parker T, Faulkner D, Vieth $R$, Vandenbroucke AC, Josse RG: Effect of high vegetable protein diets on urinary calcium loss in middle-aged men and women. Eur I Clin Nutr 2003, 57:376-382.

120. Maurer M, Riesen W, Muser J, Hulter HN, Krapf R: Neutralization of Western diet inhibits bone resorption independently of $\mathrm{K}$ intake and reduces cortisol secretion in humans. Am J Physiol Renal Physiol 2003, 284:F32-F40.

121. Schuette SA, Hegsted M, Zemel MB, Linkswiler HM: Renal acid, urinary cyclic AMP, and hydroxyproline excretion as affected by level of protein, sulfur amino acid, and phosphorus intake. J Nutr 1981, 111:2106-2116.

122. Gonick HC, Goldberg G, Mulcare D: Reexamination of the acid-ash content of several diets. Am J Clin Nutr 1968, 21:898-903.

123. Trilok G, Draper HH: Sources of protein-induced endogenous acid production and excretion by human adults. Calcif Tissue Int 1989, 44:335-338.

124. Normand M, Cayotte JL, Houillier P, Peuchant A, Paillard M: [Exaggerated calciuric response to an acute acid load in patients forming renal calcium stones]. Nephrologie 1993, 14:283-285.

125. Moriguti JC, Ferriolli E, Marchini JS: Urinary calcium loss in elderly men on a vegetable:animal (1:1) high-protein diet. Gerontology 1999, 45:274-278.

126. Lindinger MI, Franklin TW, Lands LC, Pedersen PK, Welsh DG, Heigenhauser $\mathrm{GJ}: \mathrm{NaHCO}(3)$ and $\mathrm{KHCO}(3)$ ingestion rapidly increases renal electrolyte excretion in humans. J Appl Physiol 2000, 88:540-550.

127. Lemann J Jr, Gray RW, Pleuss JA: Potassium bicarbonate, but not sodium bicarbonate, reduces urinary calcium excretion and improves calcium balance in healthy men. Kidney Int 1989, 35:688-695.

128. Lennon EJ Jr, Lemann J, Litzow JR: The effects of diet and stool composition on the net external acid balance of normal subjects. J Clin Invest 1966, 45:1601-1607.

129. Lemann J Jr, Litzow JR, Lennon EJ: The effects of chronic acid loads in normal man: further evidence for the participation of bone mineral in the defense against chronic metabolic acidosis. J Clin Invest 1966, 45:1608-1614.

130. Leskovar R: ["Drinking the waters" as a therapeutic exercise in the ionic range]. [German]. MMW - Munchener Medizinische Wochenschrift 1975 $117: 437-442$

131. Lemann J Jr, Pleuss JA, Gray RW, Hoffmann RG: Potassium administration reduces and potassium deprivation increases urinary calcium excretion in healthy adults [corrected]. Kidney Int 1991, 39:973-983.

132. Frassetto LA, Todd KM, Morris RC Jr, Sebastian A: Estimation of net endogenous noncarbonic acid production in humans from diet potassium and protein contents. Am J Clin Nutr 1998, 68:576-583.

133. Jajoo R, Song L, Rasmussen H, Harris SS, Dawson-Hughes B: Dietary acidbase balance, bone resorption, and calcium excretion. J Am Coll Nutr 2006, 25:224-230.

134. Sellmeyer DE, Schloetter M, Sebastian A: Potassium citrate prevents increased urine calcium excretion and bone resorption induced by a high sodium chloride diet. J Clin Endocrinol Metab 2002, 87:2008-2012.

135. Fenton TR, Eliasziw M, Lyon AW, Tough SC, Hanley DA: Meta-analysis of the quantity of calcium excretion associated with the net acid excretion of the modern diet under the acid-ash diet hypothesis. Am J Clin Nutr 2008, 88:1159-1166.

136. Marsh AG, Sanchez TV, Midkelsen O, Keiser J, Mayor G: Cortical bone density of adult lacto-ovo-vegetarian and omnivorous women. J Am Diet Assoc 1980, 76:148-151.

137. Remer T, Dimitriou T, Manz F: Dietary potential renal acid load and renal net acid excretion in healthy, free-living children and adolescents. Am J Clin Nutr 2003, 77:1255-1260.

138. McGartland CP, Robson PJ, Murray L, Cran GW, Savage MJ, Watkins DC, Rooney MM, Boreham CA: Fruit and vegetable consumption and bone mineral density: the Northern Ireland Young Hearts Project. Am J Clin Nutr 2004, 80:1019-1023.

139. Michaud DS, Troiano RP, Subar AF, Runswick S, Bingham S, Kipnis V, Schatzkin A: Comparison of estimated renal net acid excretion from dietary intake and body size with urine pH. J Am Diet Assoc 2003, 103:1001-1007.

140. New SA, Macdonald HM, Campbell MK, Martin JC, Garton MJ, Robins SP, Reid DM: Lower estimates of net endogenous non-carbonic acid production are positively associated with indexes of bone health in premenopausal and perimenopausal women. Am J Clin Nutr 2004, 79:131-138. 
141. Prynne CJ, Ginty F, Paul AA, Bolton-Smith C, Stear SJ, Jones SC, Prentice A: Dietary acid-base balance and intake of bone-related nutrients in Cambridge teenagers. Eur J Clin Nutr 2004, 58:1462-1471.

142. Tylavsky FA, Holliday K, Danish R, Womack C, Norwood J, Carbone L: Fruit and vegetable intakes are an independent predictor of bone size in early pubertal children. Am J Clin Nutr 2004, 79:311-317.

143. Alexy U, Remer T, Manz F, Neu CM, Schoenau E: Long-term protein intake and dietary potential renal acid load are associated with bone modeling and remodeling at the proximal radius in healthy children. Am J Clin Nutr 2005, 82:1107-1114.

144. Rafferty K, Davies KM, Heaney RP: Potassium intake and the calcium economy. J Am Coll Nutr 2005, 24:99-106.

145. Vatanparast H, Baxter-Jones A, Faulkner RA, Bailey DA, Whiting SJ: Positive effects of vegetable and fruit consumption and calcium intake on bone mineral accrual in boys during growth from childhood to adolescence: the University of Saskatchewan Pediatric Bone Mineral Accrual Study. Am J Clin Nutr 2005, 82:700-706.

146. Macdonald HM, New SA, Fraser WD, Campbell MK, Reid DM: Low dietary potassium intakes and high dietary estimates of net endogenous acid production are associated with low bone mineral density in premenopausal women and increased markers of bone resorption in postmenopausal women. Am J Clin Nutr 2005, 81:923-933.

147. Rylander $R$, Remer $T$, Berkemeyer $S$, Vormann J: Acid-base status affects renal magnesium losses in healthy, elderly persons. J Nutr 2006, 136:2374-2377.

148. Remer T, Berkemeyer S, Rylander R, Vormann J: Muscularity and adiposity in addition to net acid excretion as predictors of 24-h urinary $\mathrm{pH}$ in young adults and elderly. Eur J Clin Nutr 2007, 61:605-609.

149. Alexy $U$, Kersting $M$, Remer $T$ : Potential renal acid load in the diet of children and adolescents: impact of food groups, age and time trends. Public Health Nutr 2007, 11:300-306.

150. Whiting SJ, Boyle JL, Thompson A, Mirwald RL, Faulkner RA: Dietary protein, phosphorus and potassium are beneficial to bone mineral density in adult men consuming adequate dietary calcium. J Am Coll Nutr 2002, 21:402-409.

151. Hu JF, Zhao XH, Parpia B, Campbell TC: Dietary intakes and urinary excretion of calcium and acids: a cross-sectional study of women in China. Am J Clin Nutr 1993, 58:398-406.

152. Remer T, Manz F: Potential renal acid load of foods and its influence on urine pH. J Am Diet Assoc 1995, 95:791-797.

153. Ball D, Maughan RJ: Blood and urine acid-base status of premenopausal omnivorous and vegetarian women. Br J Nutr 1997, 78:683-693.

154. Itoh R, Nishiyama N, Suyama Y: Dietary protein intake and urinary excretion of calcium: a cross-sectional study in a healthy Japanese population. Am J Clin Nutr 1998, 67:438-444.

155. Jones G, Riley MD, Whiting S: Association between urinary potassium, urinary sodium, current diet, and bone density in prepubertal children. Am J Clin Nutr 2001, 73:839-844.

156. Sellmeyer DE, Stone $\mathrm{KL}$, Sebastian A, Cummings SR: A high ratio of dietary animal to vegetable protein increases the rate of bone loss and the risk of fracture in postmenopausal women. Study of Osteoporotic Fractures Research Group. Am J Clin Nutr 2001, 73:118-122.

157. Berkemeyer S, Vormann J, Gunther AL, Rylander R, Frassetto LA, Remer T: Renal net acid excretion capacity is comparable in prepubescence, adolescence, and young adulthood but falls with aging. J Am Geriatr SOC 2008, 56:1442-1448.

158. Gannon RH, Millward DJ, Brown JE, Macdonald HM, Lovell DP, Frassetto LA, Remer T, Lanham-New SA: Estimates of daily net endogenous acid production in the elderly UK population: analysis of the National Diet and Nutrition Survey (NDNS) of British adults aged 65 years and over. $\mathrm{Br}$ J Nutr 2008, 100:615-623.

159. Welch AA, Bingham SA, Reeve J, Khaw KT: More acidic dietary acid-base load is associated with reduced calcaneal broadband ultrasound attenuation in women but not in men: results from the EPIC-Norfolk cohort study. Am J Clin Nutr 2007, 85:1134-1141.

160. Wynn E, Lanham-New SA, Krieg MA, Whittamore DR, Burckhardt P: Low estimates of dietary acid load are positively associated with bone ultrasound in women older than 75 years of age with a lifetime fracture. J Nutr 2008, 138:1349-1354.

161. Thorpe M, Mojtahedi MC, Chapman-Novakofski K, McAuley E, Evans EM: A positive association of lumbar spine bone mineral density with dietary protein is suppressed by a negative association with protein sulfur. $J$ Nutr 2008, 138:80-85.

162. Chen YM, Ho SC, Woo JL: Greater fruit and vegetable intake is associated with increased bone mass among postmenopausal Chinese women. $\mathrm{Br} J$ Nutr 2006, 96:745-751.

163. Chan RS, Woo J, Chan DC, Cheung CS, Lo DH: Estimated net endogenous acid production and intake of bone health-related nutrients in Hong Kong Chinese adolescents. Eur J Clin Nutr 2009, 63:505-512.

164. Ausman LM, Oliver LM, Goldin BR, Woods MN, Gorbach SL, Dwyer JT: Estimated net acid excretion inversely correlates with urine $\mathrm{pH}$ in vegans, lacto-ovo vegetarians, and omnivores. J Ren Nutr 2008, 18:456-465.

165. Marsh AG, Sanchez TV, Michelsen O, Chaffee FL, Fagal SM: Vegetarian lifestyle and bone mineral density. Am J Clin Nutr 1988, 48:837-841.

166. Chan RS, Woo J, Chan DC, Lo DH, Cheung CS: Bone mineral status and its relation with dietary estimates of net endogenous acid production in Hong Kong Chinese adolescents. Br J Nutr 2008, 100:1283-1290.

167. Prynne CJ, Mishra GD, O'Connell MA, Muniz G, Laskey MA, Yan L, Prentice A, Ginty F: Fruit and vegetable intakes and bone mineral status: a cross sectional study in 5 age and sex cohorts. Am J Clin Nutr 2006, 83:1420-1428.

168. Puche RC, Feldman S: Relative importance of urinary sulfate and net acid excretion as determinants of calciuria in normal subjects. Medicina ( $B$ Aires) 1992, 52:220-224.

169. Heaney RP, Recker RR: Effects of nitrogen, phosphorus, and caffeine on calcium balance in women. J Lab Clin Med 1982, 99:46-55.

170. Lukert BP, Carey M, McCarty B, Tiemann S, Goodnight L, Helm M, Hassanein R, Stevenson C, Stoskopf M, Doolan L: Influence of nutritional factors on calcium-regulating hormones and bone loss. Calcif Tissue Int 1987, 40:119-125.

171. Heaney RP: Dietary protein and phosphorus do not affect calcium absorption. Am J Clin Nutr 2000, 72:758-761.

172. Rahbar A, Larijani B, Nabipour I, Mohamadi MM, Mirzaee K, Amiri Z: Relationship among dietary estimates of net endogenous acid production, bone mineral density and biochemical markers of bone turnover in an Iranian general population. Bone 2009, 45:876-881.

173. Zhong Y, Okoro CA, Balluz LS: Association of total calcium and dietary protein intakes with fracture risk in postmenopausal women: the 19992002 National Health and Nutrition Examination Survey (NHANES). Nutrition 2009, 25:647-654.

174. Abelow BJ, Holford TR, Insogna KL: Cross-cultural association between dietary animal protein and hip fracture: a hypothesis. Calcif Tissue Int 1992, 50:14-18.

175. Frassetto LA, Todd KM, Morris RC Jr, Sebastian A: Worldwide incidence of hip fracture in elderly women: relation to consumption of animal and vegetable foods. J Gerontol A Biol Sci Med Sci 2000, 55:M585-M592.

176. Wengreen HJ, Munger RG, West NA, Cutler DR, Corcoran CD, Zhang J, Sassano NE: Dietary protein intake and risk of osteoporotic hip fracture in elderly residents of Utah. J Bone Miner Res 2004, 19:537-545.

177. Karkkainen M, Lamberg-Allardt C: An acute intake of phosphate increases parathyroid hormone secretion and inhibits bone formation in young women. J Bone Miner Res 1996, 11:1905-1912.

178. Karp HJ, Vaihia KP, Karkkainen MU, Niemisto MJ, Lamberg-Allardt CJ: Acute effects of different phosphorus sources on calcium and bone metabolism in young women: a whole-foods approach. Calcif Tissue Int 2007, 80:251-258.

179. Nowson CA, Patchett A, Wattanapenpaiboon N: The effects of a lowsodium base-producing diet including red meat compared with a highcarbohydrate, low-fat diet on bone turnover markers in women aged 45-75 years. Br J Nutr 2009, 102:1161-1170.

180. Lin PH, Ginty F, Appel LJ, Aickin M, Bohannon A, Garnero P, Barclay D, Svetkey LP: The DASH diet and sodium reduction improve markers of bone turnover and calcium metabolism in adults. J Nutr 2003, 133:3130-3136

181. Cardinale M, Leiper J, Farajian P, Heer M: Whole-body vibration can reduce calciuria induced by high protein intakes and may counteract bone resorption: A preliminary study. J Sports Sci 2007, 25:111-119.

182. Heaney RP, Recker RR: Calcium supplements: anion effects. Bone Miner 1987, 2:433-439.

183. Calvo MS, Kumar R, Heath H III: Elevated secretion and action of serum parathyroid hormone in young adults consuming high phosphorus, low 
calcium diets assembled from common foods. J Clin Endocrinol Metab $1988,66: 823-829$.

184. Calvo MS, Heath H III: Acute effects of oral phosphate-salt ingestion on serum phosphorus, serum ionized calcium, and parathyroid hormone in young adults. Am J Clin Nutr 1988, 47:1025-1029.

185. Calvo MS, Kumar R, Heath H: Persistently elevated parathyroid hormone secretion and action in young women after four weeks of ingesting high phosphorus, low calcium diets. J Clin Endocrinol Metab 1990, 70:1334-1340.

186. Grimm M, Muller A, Hein G, Funfstuck R, Jahreis G: High phosphorus intake only slightly affects serum minerals, urinary pyridinium crosslinks and renal function in young women. Eur J Clin Nutr 2001, 55:153-161.

187. Zorbas YG, Kakurin VJ, Kuznetsov NA, Yarullin VL, Andreyev ID, Charapakhin KP: Phosphate measurements during hypokinesia and phosphate supplements in disclosing phosphate changes in hypokinetic subjects. Panminerva Med 2002, 44:243-251.

188. Zorbas YG, Kakurin VJ, Kuznetsov NA, Yarullin VL, Andreyev ID, Charapakhin KP: Phosphate deposition capacity of athletes during hypokinesia, phosphate loading, and ambulation. Biol Trace Elem Res 2002, 85:211-226.

189. Kakuris KK, Yerullis KB, Afoninos EA, Fedorov AK: Phosphate balance in phosphate supplemented and unsupplemented health subjects during and after hypokinesia. Clin Invest Med 2007, 30:E200-E209.

190. Zorbas YG, Kakuris KK, Deogenov VA, Yerullis KB: Phosphate homeotasis in healthy subjects during prolonged periodic and continuous hypokinesia. Clin Biochem 2007, 40:460-466.

191. Meunier PJ, Jenvrin C, Munoz F, De LG, Garnero P, Menz M: Consumption of a high calcium mineral water lowers biochemical indices of bone remodeling in postmenopausal women with low calcium intake. Osteoporos Int 2005, 16:1203-1209.

192. Roux S, Baudoin C, Boute D, Brazier M, De LG, De Vernejoul MC: Biological effects of drinking-water mineral composition on calcium balance and bone remodeling markers. J Nutr Health Aging 2004, 8:380-384.

193. Wynn E, Krieg MA, Aeschlimann JM, Burckhardt P: Alkaline mineral water lowers bone resorption even in calcium sufficiency: alkaline mineral water and bone metabolism. Bone 2009, 44:120-124.

194. Brandolini M, Gueguen L, Boirie Y, Rousset P, Bertiere MC, Beaufrere B: Higher calcium urinary loss induced by a calcium sulphate-rich mineral water intake than by milk in young women. Br J Nutr 2005, 93:225-231.

195. Chauveau P, Vendrely B, El HW, Barthe N, Rigalleau V, Combe C, Aparicio M: Body composition of patients on a very low-protein diet: a two-year survey with DEXA. J Ren Nutr 2003, 13:282-287.

196. Bullo M, Amigo-Correig P, Marquez-Sandoval F, Babio N, MartinezGonzalez MA, Estruch R, Basora J, Sola R, Salas-Salvado J: Mediterranean diet and high dietary acid load associated with mixed nuts: effect on bone metabolism in elderly subjects. J Am Geriatr Soc 2009, 57:1789-1798.

197. Garg A, Bonanome A, Grundy SM, Unger RH, Breslau NA, Pak CY: Effects of dietary carbohydrates on metabolism of calcium and other minerals in normal subjects and patients with noninsulin-dependent diabetes mellitus. J Clin Endocrinol Metab 1990, 70:1007-1013.

198. Block GD, Wood RJ, Allen LH: A comparison of the effects of feeding sulfur amino acids and protein on urine calcium in man. Am J Clin Nutr 1980, 33:2128-2136.

199. Houillier P, Normand M, Froissart M, Blanchard A, Jungers P, Paillard M: Calciuric response to an acute acid load in healthy subjects and hypercalciuric calcium stone formers. Kidney Int 1996, 50:987-997.

200. Whiting SJ, Anderson DJ, Weeks SJ: Calciuric effects of protein and potassium bicarbonate but not of sodium chloride or phosphate can be detected acutely in adult women and men. Am J Clin Nutr 1997, 65:1465-1472.

201. Schwille PO, Schmiedl A, Herrmann U, Schwille R, Fink E, Manoharan M: Acute oral calcium-sodium citrate load in healthy males. Effects on acidbase and mineral metabolism, oxalate and other risk factors of stone formation in urine. Methods Find Exp Clin Pharmacol 1997, 19:417-427.

202. Duff TL, Whiting SJ: Calciuric effects of short-term dietary loading of protein, sodium chloride and potassium citrate in prepubescent girls. J Am Coll Nutr 1998, 17:148-154.

203. Herrmann U, Schwille PO, Schmiedl A, Fan J, Manoharan M: Acute effects of calcium sodium citrate supplementation of a test meal on mineral homeostasis, oxalate, and calcium oxalate crystallization in the urine of healthy humans-preliminary results in patients with idiopathic calcium urolithiasis. Biomed Pharmacother 1999, 53:264-273.

204. Bell JA, Whiting SJ: Effect of fruit on net acid and urinary calcium excretion in an acute feeding trial of women. Nutrition 2004, 20:492-493.

205. Osther PJ, Engel K, Kildeberg P: Renal response to acute acid loading-an organ physiological approach. Scand J Urol Nephrol 2004, 38:62-68.

206. Whiting SJ, Muirhead JA: Measurement of net acid excretion by use of paper strips. Nutrition 2005, 21:961-963.

207. Heaney RP, Rafferty K: Carbonated beverages and urinary calcium excretion. Am J Clin Nutr 2001, 74:343-347.

208. Reiss E, Canterbury JM, Bercovitz MA, Kaplan EL: The role of phosphate in the secretion of parathyroid hormone in man. J Clin Invest 1970, 49:2146-2149.

209. Renier JC, Giraud P, Girardeau C, Jallet P, Gillabert P, Audran M: [Investigation of phosphorus calcium metabolism after oral phosphorus supplementation]. Rev Rhum Mal Osteoartic 1992, 59:537-544.

210. Silverberg SJ, Shane E, Clemens TL, Dempster DW, Segre GV, Lindsay R, Bilezikian JP: The effect of oral phosphate administration on major indices of skeletal metabolism in normal subjects. J Bone Miner Res 1986, 1:383-388.

211. Brixen K, Nielsen HK, Charles P, Mosekilde L: Effects of a short course of oral phosphate treatment on serum parathyroid hormone(1-84) and biochemical markers of bone turnover: a dose-response study. Calcif Tissue Int 1992, 51:276-281.

212. Thomas WC Jr, Lewis AM, Bird ED: Effect of alkali administration on calcium metabolism. J Clin Endocrinol Metab 1967, 27:1328-1336.

213. Lau K, Wolf C, Nussbaum P, Weiner B, DeOreo P, Slatopolsky E, Agus Z, Goldfarb S: Differing effects of acid versus neutral phosphate therapy of hypercalciuria. Kidney Int 1979, 16:736-742.

214. Heyburn PJ, Robertson WG, Peacock M: Phosphate treatment of recurrent calcium stone disease. Nephron 1982, 32:314-319.

215. Sakhaee K, Nicar M, Hill K, Pak CY: Contrasting effects of potassium citrate and sodium citrate therapies on urinary chemistries and crystallization of stone-forming salts. Kidney Int 1983, 24:348-352.

216. Uribarri J, Douyon H, Oh MS: A re-evaluation of the urinary parameters of acid production and excretion in patients with chronic renal acidosis. Kidney Int 1995, 47:624-627.

217. Kamel KS, Cheema-Dhadli S, Halperin ML: Studies on the pathophysiology of the low urine $\mathrm{pH}$ in patients with uric acid stones. Kidney Int 2002, 61:988-994.

218. Pak CY, Peterson RD, Poindexter J: Prevention of spinal bone loss by potassium citrate in cases of calcium urolithiasis. J Urol 2002, 168:31-34

219. Spencer H, Menczel J, Lewin I, Samachson J: Effect of high phosphorus intake on calcium and phosphorus metabolism in man. J Nutr 1965, 86:125-132.

220. Berkelhammer C, Wood RJ, Sitrin MD: Inorganic phosphorus reduces hypercalciuria during total parenteral nutrition by enhancing renal tubular calcium absorption. JPEN J Parenter Enteral Nutr 1998, 22:142-146.

221. Frassetto $L A$, Nash $E$, Morris RC Jr, Sebastian A: Comparative effects of potassium chloride and bicarbonate on thiazide-induced reduction in urinary calcium excretion. Kidney Int 2000, 58:748-752.

222. Jourdan M, Glock C, Margen S, Bradfield RB: Sulphate, acid-base, and mineral balances of obese women during weight loss. Am J Clin Nutr 1980, 33:236-243.

223. Reddy ST, Wang CY, Sakhaee K, Brinkley L, Pak CY: Effect of lowcarbohydrate high-protein diets on acid-base balance, stone-forming propensity, and calcium metabolism. Am J Kidney Dis 2002, 40:265-274

224. Bell JD, Margen S, Calloway DH: Ketosis, weight loss, uric acid, and nitrogen balance in obese women fed single nutrients at low caloric levels. Metabolism 1969, 18:193-208.

225. Vazquez JA, Adibi SA: Protein sparing during treatment of obesity: ketogenic versus nonketogenic very low calorie diet. Metabolism 1992, 41:406-414.

226. Camien MN, Smith LM, Reilly TJ, Simmons DH: Determination of total cation-forming mineral elements in feces and urine and its relation to renal "net acid" excretion. Proc Soc Exp Biol Med 1966, 123:686-691.

227. Barzel US: The effect of excessive acid feeding on bone. Calcif Tissue Res 1969, 4:94-100.

228. Sugiura S, Inagaki K, Noda Y, Nagai T, Nabeshima T: Acid load during total parenteral nutrition: comparison of hydrochloric acid and acetic acid on plasma acid-base balance. Nutrition 2000, 16:260-263. 
229. Tucker KL, Hannan MT, Chen H, Cupples LA, Wilson PW, Kiel DP: Potassium, magnesium, and fruit and vegetable intakes are associated with greater bone mineral density in elderly men and women. Am J Clin Nutr 1999, 69:727-736.

230. Kerstetter JE, Caseria DM, Mitnick ME, Ellison AF, Gay LF, Liskov TA, Carpenter TO, Insogna KL: Increased circulating concentrations of parathyroid hormone in healthy, young women consuming a proteinrestricted diet. Am J Clin Nutr 1997, 66:1188-1196.

231. Chen FC: [Acid-ash food, alkaline-ash food and neutral-ash food]. Hu Li Za Zhi 1971, 18:69-70.

232. Cloutier GR, Barr SI: Protein and bone health: literature review and counselling implications. Can J Diet Pract Res 2003, 64:5-11.

233. Morris RC Jr, Schmidlin O, Tanaka M, Forman A, Frassetto L, Sebastian A: Differing effects of supplemental $\mathrm{KCl}$ and $\mathrm{KHCO}$ : pathophysiological and clinical implications. Semin Nephrol 1999, 19:487-493.

234. Morris RC, Sebastian A: Treatment of osteoporosis using potassium bicarbonate260856[5171583]CA, USA..

235. Bleich HL, Moore MJ, Lemann J Jr, Adams ND, Gray RW: Urinary calcium excretion in human beings. $N$ Engl J Med 1979, 301:535-541.

236. Kleinman JG, Lemann J Jr: Acid production. In Clincal disorders of fluid and electrolyte metabolism. Edited by: Maxwell MH, Kleeman CR, Narins RG. New York: McGraw Hill; 1987:159-173.

237. Alpern RJ, Sakhaee K: The clinical spectrum of chronic metabolic acidosis: homeostatic mechanisms produce significant morbidity. Am J Kidney Dis 1997, 29:291-302.

238. Barzel US, Massey LK: Excess dietary protein can adversely affect bone. $J$ Nutr 1998, 128:1051-1053.

239. Remer T: Influence of diet on acid-base balance. Semin Dial 2000, 13:221-226.

240. Frassetto L, Morris RC Jr, Sellmeyer DE, Todd K, Sebastian A: Diet, evolution and aging-the pathophysiologic effects of the post-agricultural inversion of the potassium-to-sodium and base-to-chloride ratios in the human diet. Eur J Nutr 2001, 40:200-213.

241. Remer $\mathrm{T}$ : Influence of nutrition on acid-base balance-metabolic aspects. Eur J Nutr 2001, 40:214-220.

242. Sebastian A, Frassetto LA, Sellmeyer DE, Merriam RL, Morris RC Jr: Estimation of the net acid load of the diet of ancestral preagricultural Homo sapiens and their hominid ancestors. Am J Clin Nutr 2002, 76:1308-1316

243. Lemann J Jr, Bushinsky DA, Hamm LL: Bone buffering of acid and base in humans. Am J Physiol Renal Physiol 2003, 285:F811-F832.

244. Frassetto LA, Schloetter M, Mietus-Synder M, Morris RC Jr, Sebastian A: Metabolic and physiologic improvements from consuming a paleolithic, hunter-gatherer type diet. Eur J Clin Nutr 2009, 63:947-955

245. Mann NJ: Paleolithic nutrition: what can we learn from the past? Asia Pac J Clin Nutr 2004, 13:S17.

246. Prentice A, Schoenmakers I, Laskey MA, de BS, Ginty F, Goldberg GR: Nutrition and bone growth and development. Proc Nutr Soc 2006, 65:348-360.

247. Lanham-New SA: The balance of bone health: tipping the scales in favor of potassium-rich, bicarbonate-rich foods. J Nutr 2008, 138:172S-177S.

248. Eaton SB, Eaton SB III: Paleolithic vs. modern diets-selected pathophysiological implications. Eur J Nutr 2000, 39:67-70.

249. Cordain L, Eaton SB, Sebastian A, Mann N, Lindeberg S, Watkins BA, O'Keefe $\mathrm{JH}$, Brand-Miller J: Origins and evolution of the Western diet: health implications for the 21st century. Am J Clin Nutr 2005, 81:341-354.

250. Eaton SB: The ancestral human diet: what was it and should it be a paradigm for contemporary nutrition? Proc Nutr Soc 2006, 65:1-6.

251. Demigne C, Sabboh H, Puel C, Remesy C, Coxam V: Organic anions and potassium salts in nutrition and metabolism. Nutr Res Rev 2004, 17:249-258.

252. Krapf R: Partial neutralization of the acidogenic Western diet with potassium citrate increases bone mass in postmenopausal women with osteopenia. Interview by Nicola Zitzmann. Int J Prosthodont 2007, 20:113-114.

253. Heaney RP, Layman DK: Amount and type of protein influences bone health. Am J Clin Nutr 2008, 87:1567S-1570S.

254. Pizzorno J, Frassetto LA, Katzinger J: Diet-induced acidosis: is it real and clinically relevant? Br J Nutr 2010, 103:1185-1194.
255. Wynn E, Krieg MA, Lanham-New SA, Burckhardt P: Postgraduate Symposium: Positive influence of nutritional alkalinity on bone health. Proc Nutr Soc 2010, 69:166-173.

256. McCarty MF: Should we restrict chloride rather than sodium? Med Hypotheses 2004, 63:138-148.

257. McCarty MF: Rationale for a novel nutraceutical complex 'K-water': potassium taurine bicarbonate (PTB). Med Hypotheses 2006, 67:65-70

258. Frassetto LA, Morris RC Jr, Sellmeyer DE, Sebastian A: Adverse effects of sodium chloride on bone in the aging human population resulting from habitual consumption of typical American diets. J Nutr 2008, 138:419S-422S

259. Davison KS, Siminoski K, Adachi JD, Hanley DA, Goltzman D, Hodsman AB, Josse R, Kaiser S, Olszynski WP, Papaioannou A, Ste-Marie LG, Kendler DL, Tenenhouse A, Brown JP: The effects of antifracture therapies on the components of bone strength: assessment of fracture risk today and in the future. Semin Arthritis Rheum 2006, 36:10-21.

260. Davison KS, Siminoski K, Adachi JD, Hanley DA, Goltzman D, Hodsman AB, Josse R, Kaiser S, Olszynski WP, Papaioannou A, Ste-Marie LG, Kendler DL, Tenenhouse A, Brown JP: Bone strength: the whole is greater than the sum of its parts. Semin Arthritis Rheum 2006, 36:22-31.

261. Pellegrino ED, Biltz RM: The composition of human bone in uremia. Medicine (Baltimore) 1965, 44:397-418.

262. Silver IA, Murrills RJ, Etherington DJ: Microelectrode studies on the acid microenvironment beneath adherent macrophages and osteoclasts. Exp Cell Res 1988, 175:266-276.

263. Schurch MA, Rizzoli R, Slosman D, Vadas L, Vergnaud P, Bonjour JP: Protein supplements increase serum insulin-like growth factor-I levels and attenuate proximal femur bone loss in patients with recent hip fracture. A randomized, double-blind, placebo-controlled trial. Ann Intern Med $1998,128: 801-809$

264. Tengstrand B, Cederholm T, Soderqvist A, Tidermark J: Effects of proteinrich supplementation and nandrolone on bone tissue after a hip fracture. Clin Nutr 2007, 26:460-465

265. Sherman HC, Sinclair JE: The balance of acid-forming and base-forming elements in foods. J Biol Chem 1907, 3:307-309.

266. Oster JR, Lopez R, Perez GO, Alpert HA, Al Reshaid KA, Vaamonde CA: The stability of $\mathrm{pH}, \mathrm{PCO} 2$, and calculated [HCO3] of urine samples collected under oil. Nephron 1988, 50:320-324.

267. Lemann J Jr, Lennon EJ, Brock J: A potential error in the measurement of urinary titratable acid. J Lab Clin Med 1966, 67:906-913.

268. Camacho PM, Lopez NA: Use of biochemical markers of bone turnover in the management of postmenopausal osteoporosis. Clin Chem Lab Med 2008, 46:1345-1357.

269. Smith-Warner SA, Spiegelman D, Yaun SS, Albanes D, Beeson WL, van den Brandt PA, Feskanich D, Folsom AR, Fraser GE, Freudenheim JL, Giovannucci E, Goldbohm RA, Graham S, Kushi LH, Miller AB, Pietinen P, Rohan TE, Speizer FE, Willett WC, Hunter DJ: Fruits, vegetables and lung cancer: a pooled analysis of cohort studies. Int J Cancer 2003, 107:1001-1011.

270. Arjmandi BH, Khalil DA, Lucas EA, Georgis A, Stoecker BJ, Hardin C, Payton ME, Wild RA: Dried plums improve indices of bone formation in postmenopausal women. J Womens Health Gend Based Med 2002, $11: 61-68$.

271. Muhlbauer RC, Lozano A, Reinli A: Onion and a mixture of vegetables, salads, and herbs affect bone resorption in the rat by a mechanism independent of their base excess. J Bone Miner Res 2002, 17:1230-1236.

doi:10.1186/1475-2891-10-41

Cite this article as: Fenton et al: Causal assessment of dietary acid load and bone disease: a systematic review \& meta-analysis applying Hill's epidemiologic criteria for causality. Nutrition Journal 2011 10:41. 